\title{
A decade of EU law in the courts of Scotland and Ireland: national legal systems compared
}

\author{
Barry Rodger ${ }^{1 \star}$ (D) Imelda Maher $^{2}$ (D) and Rónán Riordan ${ }^{3}$ \\ ${ }^{1}$ University of Strathclyde, Glasgow, Scotland, ${ }^{2}$ University College Dublin, Dublin, Ireland and ${ }^{3}$ Hertie School, Berlin, \\ Germany \\ *Corresponding author e-mail: barry.j.rodger@strath.ac.uk
}

(Accepted 15 September 2020)

\begin{abstract}
This paper presents the findings of a comparative statistical study examining the application and trends in the deployment and utilisation of European Union (EU) law before the Scottish and Irish courts over a 10-year period from 2009-2018. The paper poses the question, how does European integration impact on the domestic legal systems of EU Member States due to the increasing volume, and significance, of cases where EU law is raised and applied within domestic legal systems? The research presented is of particular relevance in light of Brexit. It allows prescient reflection on the significant disruption and impact the United Kingdom's exit from the EU is likely to have on areas of domestic law which are highly integrated with EU law. It highlights the potential difficulties implicit in attempting to unpick over 40 years of assimilation of EU law and principles into Scots law. These research outcomes should lead to further reflection and debate on the role of EU law and its impact on judicial decision-making in the Scottish and Irish legal systems in general.
\end{abstract}

Keywords: EU law; Scotland; Ireland; national legal systems; Brexit

\section{Introduction}

'Community law has a habit of emerging in unlikely corners'.

'Since Ireland joined the European Economic Community in 1973 the reach of European Union law into the legal systems of all of the member states has grown to a very significant extent'.

This study provides an analysis of judgments in civil law cases of the Scottish courts and the Irish ${ }^{3}$ Superior Courts in which EU law has arisen during the period of 2009 through to the end of $2018 .{ }^{4}$ It

\footnotetext{
${ }^{1}$ Per Boch and Lane referring to Lord Mackenzie Stuart presenting at the $29^{\text {th }}$ Hamlyn Lectures in 1999 on 'The European Communities and the rule of law'. See C Boch and R Lane 'European Community law au pays du tartan' in H MacQueen (ed) Scots Law into the 21st Century: Essays in Honour of WA Wilson (Edinburgh: W Green, 1996).

${ }^{2}$ Per The Hon Mr Justice Frank Clarke, Chief Justice of Ireland, speaking at the Institute of International and European Affairs in Dublin 21 November 2018 on 'Ireland as a dispute resolution hub after Brexit'. See also Chief Justice Frank Clarke 'Apex court dialogue: the view from Dublin' (2019) 1 Irish Supreme Court Review 1.

${ }^{3}$ For the Irish study a full-scale analysis of every EU law judgment issued within the 10-year period would have involved reviewing potentially thousands of cases based on preliminary research undertaking. As such a more targeted and precise search was formulated which confined results to cases where not only was EU law mentioned, but the search indicated there was more substantive engagement by the Irish Court with the EU law issue. The search carried out therefore excluded cases where an EU legislative instrument was mentioned, with no other words in the judgment which would indicate engagement with the EU law issue. For example, a single reference to Council Directive 92/43/EEC on the conservation of natural habitats and of wild fauna and flora [2001] OJ L 206/7 would not have been sufficient for a case to appear in the search results to be reviewed for the creation of the Irish dataset.

${ }^{4}$ The exact dates of the study are 1 January 2009-31 December 2018.

(C) The Author(s), 2021. Published by Cambridge University Press. This is an Open Access article, distributed under the terms of the Creative Commons Attribution licence (http://creativecommons.org/licenses/by/4.0/), which permits unrestricted re-use, distribution, and reproduction in any medium, provided the original work is properly cited.
} 
offers a comparative quantitative analysis of the case law with a view to drawing conclusions about the role of EU law within domestic senior courts, in Scotland and Ireland. ${ }^{5}$ This study follows earlier work by one of the co-authors examining the impact of EU law on Scots law and decision-making by the judiciary in the Scottish legal system over the period of 40 years to $2015 .{ }^{6}$ Comparison is being drawn between the two jurisdictions in order to examine the extent to which EU law has become embedded in them, what differences there are between them, and how this experience is likely to change for both in different ways in light of Brexit. ${ }^{7}$

The paper first briefly sets the context by locating the research in wider empirical studies on EU law and, more specifically, on EU law in Scotland and Ireland. It then outlines the context of the study before turning to how EU law was incorporated into domestic law in the two jurisdictions and the relevant key EU doctrines. The methodology used is explained and the results are outlined and analysed before concluding.

\section{Empirical research and EU law studies}

Lawyers have a tendency, as noted by Burns and Hutchinson, to view law as a closed system with doctrinal research the primary methodology to explore law as a social system. ${ }^{8}$ The American legal realist movement was perhaps the first to recognise the importance of studying law 'in action' as opposed to the law 'on books' through empirical work, with Miles and Sunstein recently coining the phrase 'The New Legal Realism'. ${ }^{9}$ This paper is a quantitative study of case law, building on the law and politics literature that emerged in the late 1990s. Stone Sweet and Brunell demonstrated how transnational exchange, triadic dispute resolution, and the production of legal norms operated to progressively reduce the ability of national governments to control policy outcomes within the then 'European Community' (EC). ${ }^{10}$ Stone Sweet and Sandholtz's theory of EC legal integration ${ }^{11}$ was tested by Stone Sweet and Caporaso, who demonstrated the compatibility of the theory with the data. ${ }^{12}$ Conant's work illustrated that the majority of national court decisions involving EU law did not involve references to the case law of the Court of Justice of the European Union (CJEU), with French, British and German judges more likely to cite provisions of EU law such as treaties, directives or regulations rather than the jurisprudence of the CJEU. ${ }^{13}$ Alter demonstrated how the supranational legal order contributed to judicial competition between lower courts and higher courts within Member

\footnotetext{
${ }^{5}$ Under Art 4 of the Constitution of Ireland the official name of the state is Ireland ('Éire' in the Irish language) and the 'Republic of Ireland' is a description of the state under Republic of Ireland Act 1948 (Ireland), s 2. In the UK, under the Ireland Act 1949 (UK), s 1(3) the state was to be referred to as the Republic of Ireland. For an excellent discussion of the complexities here see M Daly 'The Irish Free State/Éire/Republic of Ireland/Ireland: "a country by any other name"?' (2007) 46(1) Journal of British Studies 72.

${ }^{6}$ See B Rodger 'The application of EU law by the Scottish courts: an analysis of case-law trends over forty years' (2017) Juridical Review 59; see also the very limited discussion in J Shaw 'Scotland: 40 years of EU membership' (2012) 8(4) Journal of Contemporary European Research 547. For a discussion of EU law in Irish courts in recent years see I Maher 'EU law and the courts: the mundane and the exceptional' in E Carolan (ed) Judicial Power in Ireland (Dublin: IPA, 2018).

${ }^{7}$ See generally G Hogan 'Laws in common? What is the future of the common law within the European Union after Brexit?'(2019) 24(1) The Irish Bar Review 22; see also S Da Lomba et al 'Scottish legal education after Brexit' (2019) 53 (2) The Law Teacher 138.

${ }^{8}$ K Burns and T Hutchinson 'The impact of "empirical facts" on legal scholarship and legal research training' (2009) 43(2) The Law Teacher 158.

${ }^{9}$ TJ Miles and CR Sunstein 'The new legal realism' (2008) 75 University of Chicago Law Review 832; P Cane and HM Kritzer (eds) The Oxford Handbook of Empirical Legal Research (Oxford: Oxford University Press, 2010) p 2.

${ }^{10}$ A Stone Sweet and TL Brunell 'Constructing a supranational constitution: dispute resolution and governance in the European Community’ (1998) 92(1) American Political Science Review 63.

${ }^{11}$ A Stone Sweet and W Sandholtz 'Integration, supranational governance, and the institutionalization of the European polity' in W Sandholtz and A Stone Sweet European Integration and Supranational Governance (Oxford: Oxford University Press, 1998). See in particular pp 4-7.

${ }^{12}$ See generally A Stone Sweet and J Caporaso 'From free trade to supranational polity: the European Court and integration' in Sandholtz and Stone Sweet, above n 11.

${ }^{13}$ See for example L Conant Justice Contained (Ithaca, NY: Cornell University Press, 2002) pp 81-83.
} 
States in the context of their relationship with the CJEU. ${ }^{14}$ Chalmers' examination of claims based on EU law before courts in the UK showed litigants' success where EU law extended state powers, whereas they were less successful when EU law restricted the state's control, for example in issues relating to immigration and criminal law. ${ }^{15}$

Within the context of Scotland and Ireland, there has been comparatively little quantitative research on EU law in their courts, with notable exceptions. Rodger's work on EU law before the Scottish courts $^{16}$ showed an increase in the impact of EU law in the civil justice system in Scotland, in both private and public law aspects, in the first 40 years of UK membership. His statistical analysis suggests this was due to three related factors: first, an increased quantity and subject-matter coverage of EU law; second, a greater awareness of EU law and EU law rights by parties and their legal advisers; and third, an increased focus in recent years on the principle of effective judicial protection. ${ }^{17}$

In Ireland, Fahey's seminal work examined the practices and procedures of EU law before the Irish courts on the preliminary reference procedure over a 30-year period from Ireland's accession to the EU in 1973, with this research updated by her in $2013 .{ }^{18}$ Within the first three decades of Ireland's EU membership 44 preliminary references to the CJEU were recorded, a low figure even taking into account its population and the number of courts within the state. ${ }^{19}$ However, this narrative changed in later years with an observable increase in the number of references originating from the Supreme Court between 2003 and 2013, and reversal of the previous trend of the Irish High Court making the greatest number of references. ${ }^{20}$ Fahey's observations mirror that of Alter, who argued that in the early days of the EU, Member States' lower courts were more likely to make references to the CJEU than higher courts, with higher courts over time becoming more open to making references to the CJEU as they sought to re-assert their position within national legal orders, ${ }^{21}$ a trend discernible in Fahey's data. Maher, in her examination of EU law before the Irish courts, noted that between March 2013 and June 2017 there had been 24 references to the CJEU from all courts and tribunals in Ireland, covering a wide range of issues such as: repeat arrests in light of the charter of fundamental rights; discrimination of same-sex partners and pension entitlements; European Arrest Warrants; and applications of subsidiary protection. ${ }^{22}$ This is broadly similar to the data collected by Krommendijk, who noted that there were 15 references from Irish lower courts (defined as all courts and tribunals below the Supreme Court) between 2013 and 2016, representing 65\% of references from Ireland. ${ }^{23}$ This data on Irish referral rates is in line with wider European trends ${ }^{24}$ and demonstrates the degree to which EU law has become an ordinary part of the Irish legal system. ${ }^{25}$

\footnotetext{
${ }^{14}$ K Alter 'The European Court's political power' (1996) 19(3) West European Politics 458; K Alter Establishing the Supremacy of European Law (New York: Oxford University Press, 2001); K Alter 'Private litigants and the new international courts' (2006) 39(1) Comparative Political Studies 22.

${ }^{15} \mathrm{D}$ Chalmers 'The positioning of EU judicial politics within the United Kingdom' (2000) 23(4) West European Politics 169.

${ }^{16}$ See B Rodger 'The application of EU law by the Scottish courts: an analysis of case-law trends over forty years' (2017) Juridical Review 59.

${ }^{17}$ A Arnull 'The principle of effective judicial protection in EU law; an unruly horse?' (2011) 36(1) European Law Review 51. More recently, Klamert discusses the relationship between effective judicial protection and the wider principle of effectiveness which requires Member States to take the measures necessary to ensure EU law is complied with: see M Klamert The Principle of Loyalty in EU Law (Oxford: Oxford University Press, 2014) ch 6.

${ }^{18}$ E Fahey Practice and Procedure in Preliminary References to Europe: 30 Years of Article 234 EC Case Law from the Irish Courts (Dublin: First Law, 2007); E Fahey 'EU law and Ireland: on the measurement of legal evolutions through judicial activity' (12 March 2013), available at SSRN: https://ssrn.com/abstract=2232226 or http://dx.doi.org/10.2139/ssrn.2232226.

${ }^{19}$ Fahey (2007), above n 18.

${ }^{20}$ Fahey (2013), above n 18, p 9.

${ }^{21}$ Alter (1996), above n 14, at 467 and 470.

${ }^{22}$ Maher, above n 6, pp 179-182.

${ }^{23} \mathrm{~J}$ Krommendijk 'Why do lower courts refer in the absence of a legal obligation? Irish eagerness and Dutch disinclination' (2019) 26(6) Maastricht Journal of European and Comparative Law 772.

${ }^{24}$ Ibid.

${ }^{25}$ Maher, above n 6, p 173.
} 


\section{Scotland and Ireland: context compared}

This paper provides an updated account of these two jurisdictions at a critical juncture, with Brexit changing the role of EU law in Scottish courts ${ }^{26}$ and the Irish legal system set to become the largest common law jurisdiction within the EU. ${ }^{27}$ This comparative account, through equivalent statistical analyses of EU case law in both jurisdictions over the last ten years, sheds light on the extent to which EU law has been embedded and normalised within the legal culture of both jurisdictions, how lawyers used EU law in their litigation strategies, and provides insights as to how domestic courts interact with both EU law and the CJEU. Additionally, it highlights differences between the two legal orders. $^{28}$

While Scotland is a part of the UK, its courts have similar competence to deal with any private or public law-related disputes (subject to the appropriate rules on jurisdiction) ${ }^{29}$ as the Irish courts. Scotland and Ireland share broadly similar demographics. Each has its own distinct legal system, and their populations are similar (Ireland has a population of $4.761 \mathrm{~m}$ as of 2016 and Scotland a population of $5.438 \mathrm{~m}$ as of mid-2018). ${ }^{30}$ Scotland currently has over 11,000 qualified solicitors and circa 460 Advocates at the Bar; ${ }^{31}$ Ireland has 10,466 solicitors with practicing certificates with far more practicing barristers: currently 2,300, reflecting greater activity in the courts. ${ }^{32}$ Scottish court statistics demonstrate that in the most recent year for which there is data (2017-18), the Scottish civil courts disposed of 69,099 cases, an annual figure which has steadily reduced from a high in 2008-09 of 115,363 cases. $^{33}$ In Ireland, there were 178,046 civil cases resolved in 2018 by all Irish courts, of this figure 31,742 cases were resolved by the Irish Superior Courts which form the focus of this study. ${ }^{34}$ Like Scotland the 2018 figure represents a decrease on the 36,255 civil cases resolved by the Superior Courts in 2013. ${ }^{35}$ These figures, taken in conjunction with the data gathered for this study, indicate that only a fraction of case law raised EU law.

\footnotetext{
${ }^{26}$ The European Union (Withdrawal) Act 2018 (UK), ss 2-7 make provision to ensure that most existing provisions of EU law are retained as part of Scots law (as part of the UK) but new EU rules after that date will not be incorporated. See also the European Union (Withdrawal Agreement) Act 2020 (UK), ss 25-26.

${ }^{27}$ Cyprus and Malta have more hybrid common law systems. On Cyprus see generally NE Hatzimiail 'Cyprus as a mixed legal system' (2013) 6(1) Journal of Civil Law Studies 39. On Malta see B Andó 'The role of judges in the development of mixed legal systems: the case of Malta' (2011) 4(2) Journal of Civil Law Studies 237.

${ }^{28}$ For discussion of how practices differ in national courts across the EU see B de Witte et al National Courts and EU Law: New Issues, Theories and Methods (Cheltenham: Edward Elgar, 2016) ch 2; see generally G Martinico and O Pollicino (eds) The National Judicial Treatment of the ECHR and EU Laws: A Comparative Constitutional Perspective (Europa Law Publishing, 2010).

${ }^{29}$ See G Maher and B Rodger Civil Jurisdiction in the Scottish Courts (Edinburgh: W Green \& Son, 2010).

${ }^{30}$ Central Statistics Office, Press Release - Census 2016 Summary Results - Part 1, p 1 available at https://www.cso.ie/en/ media/csoie/newsevents/documents/pressreleases/2017/prCensussummarypart1.pdf; https://www.nrscotland.gov.uk/statistics-and-data/statistics/scotlands-facts/population-of-scotland.

${ }^{31} 11,592$ as at end of 2018, according to the Annual Report of the Law Society of Scotland 2018, https://www.lawscot.org.uk/ about-us/strategy-reports-plans/annual-reports/annual-report-2018.

${ }^{32}$ For solicitors see the Law Society of Ireland's Annual Report and Accounts for 2017/2018 with figures accurate as of 25 October 2018; report available at https://www.lawsociety.ie/globalassets/documents/about-us/annual-reports/annualreport2018_finalweb.pdf; for barristers see the Bar of Ireland's official website, available at https://www.lawlibrary.ie/AboutUs.aspx.

${ }^{33}$ There was only an increase between 2016-17 and 2017-18: see Civil Justice Statistics in Scotland 2017-18, 2 April 2019, https://www.gov.scot/publications/civil-justice-statistics-scotland-2017-18/pages/1/.

${ }^{34}$ Court Service Annual Report 2018 p 47, available at https://www.courts.ie/acc/alfresco/d3167a7a-2b47-4fc2-b6546e657df2a01d/Courts\%20Service\%20Annual\%20Report\%202018.pdf/pdf\#view=fitH.

${ }^{35}$ A reduction of 12.45\%. See Court Service Annual Report 2013 p 27, available at https://www.courts.ie/acc/alfresco/7370920c50be-4d93-82ec-346a016cdd49/Courts\%20Service\%20Annual\%20Report\%202013.pdf/pdf\#view=fitH; comparative figures for Ireland with regard to civil business cases resolved by the Superior Courts are not publicly available for the period 2008-09. It is possible that a rise in the use of alternative dispute resolution (ADR) mechanisms may be contributing an overall decrease in civil cases before the Irish courts generally, however consistent data documenting the prevalence of ADR in Ireland is not available. For a discussion as to ADR in Ireland see G Palao Moreno 'Ireland' in C Esplugues et al Civil and Commercial Mediation in Europe (Intersentia, 2014) p 233.
} 


\section{Incorporation of EU Law into the domestic legal orders}

The UK and Ireland both joined the then European Economic Community (EEC, now the EU) on 1 January $1973 .^{36}$ A referendum was held in Ireland, which permitted the amendment of the Irish Constitution and allowed the state to join the EEC. As a dualist state the Oireachtas (the Irish Parliament) legislated for the incorporation of EEC law into the domestic system through the European Communities Act $1972 .{ }^{37}$ In the UK, the process similarly required an Act of Parliament, the European Communities Act $1972 .{ }^{38}$ At the time of membership, the CJEU had already set down two major doctrines that distinguish EU law from international law. First, EU law has primacy over national law (the primacy doctrine) where there is a conflict between EU and national law, ${ }^{39}$ and second, where EU law is directly effective, it produces rights and obligations for individuals that national courts are required to enforce (the doctrine of direct effect). ${ }^{40}$ These doctrines, coupled with the preliminary reference procedure (whereby questions of interpretation or validity of EU law can be sent by a national court to the CJEU for consideration) provide a means through which national courts may seek the CJEU's authoritative ruling on EU law. ${ }^{41}$ In addition, the EU Treaty requires Member States to provide remedies that will ensure effective legal protection for EU law. ${ }^{42}$ These obligations, underpinned by the principle of equivalence, ${ }^{43}$ are applied subject to the procedural autonomy of national courts. In the wake of the CJEU judgment in Francovich, ${ }^{44}$ the CJEU held that damages could be awarded by national courts for breach of EU law. The effect of these doctrines, as this study would suggest, is that while the overall volume of EU law before national courts may be small, it is of growing significance in higher courts and in particular fields of law. ${ }^{45} \mathrm{EU}$ law's

\footnotetext{
${ }^{36}$ The European Economic Community was renamed the European Community in Art G(A)(1) Treaty of Maastricht; The European Union then replaced and succeeded the European Community via Art 1(b) Treaty of Lisbon.

${ }^{37}$ The Third Amendment of the Constitution Act 1972 (Ireland) was passed by referendum on 10 May 1972 and inserted Art 29.4.3 to the Constitution of Ireland. The Referendum was carried $83.10 \%$ of voters. The European Communities Act, 1972 (Ireland), s 2 explicitly states that 'From the 1st day of January, 1973, the treaties governing the European Communities and the existing and future acts adopted by the institutions of those Communities shall be binding on the State and shall be part of the domestic law thereof under the conditions laid down in those treaties'.

${ }^{38}$ The European Communities Act 1972 (UK), repealed by the European Union (Withdrawal) Act 2018 (UK), s 1. It ceased to have effect at the end of the Brexit transition period (31 December 2020). See the European Union (Withdrawal Agreement) Act 2020 (UK), s 39(1).

${ }^{39}$ Case C-6/64 Costa $v$ ENEL [1964] ECR 585; M Avbelj 'Supremacy or primacy of EU law-(why) does it matter?' (2011) 17 ELJ 744; JH Reestman 'Primacy of Union law' (2005) 1 European Constitutional Law Review 104.

${ }^{40}$ The scope of the doctrine depends on the extent to which the legal provision invoked is clear and unconditional, and whether the defendant is the state or a private person. The doctrine has been refined and developed over the years since the foundational case of C-26/62 van Gend en Loos [1963] ECR 1. See M Poares Maduro and L Azoulai (eds) The Past and Future of EU Law: The Classics of EU Law Revisited on the 50th Anniversary of the Rome Treaty (Oxford: Hart Publishing, 2010) pp 1-31; D Chalmers and L Barroso 'What Van Gend en Loos stands for' (2014) 12(1) International Journal of Constitutional Law 105; M Rasmussen 'Revolutionizing European law: a history of the Van Gend en Loos judgment' (2014) 12(1) International Journal of Constitutional Law 136. See generally D Chalmers et al European Union Law (Cambridge: Cambridge University Press, $4^{\text {th }}$ edn, 2019) ch 7.

${ }^{41}$ Art 267 Treaty on the Functioning of the European Union. The CJEU is the sole authoritative interpreter of EU law, see Arts 17 and 19(3) TEU. On the preliminary reference procedure see M Claes 'Luxembourg, here we come? Constitutional courts and the preliminary reference procedure' (2015) 16(6) German Law Journal 1331.

${ }^{42}$ Art 19(1) Treaty on European Union. The EU Charter also guarantees effective remedies where rights and freedoms have been violated: see Art 47 EU Charter of Fundamental Rights and Freedoms.

${ }^{43}$ On equivalence see Case C-14/83 Von Colson v Land Nordrhein-Westfalen [1984] ECR 1891. See generally P Craig and G de Búrca EU Law: Text, Cases, and Materials (Oxford: Oxford University Press, 7th edn, 2020) ch 9; A Kaczorowska-Ireland European Union Law (Routledge, 2016) p 380; see Arnull, above n 17, for an analysis of the interplay of the principles of procedural autonomy, judicial effectiveness and equivalence of remedies.

${ }^{44}$ Cases C-6/90 and C-9/90 Francovich and Bonifaci $v$ Republic of Italy ECLI:EU:C:1991:428.

${ }^{45}$ However, it is important to note that the impact of Francovich may not yet have been fully realised in some Member States and their legal systems. See in particular the work of Lock, who notes through his statistical studies that in the case of the English and German courts few Francovich claims have been brought, and fewer have been successful: T Lock 'Is private enforcement of EU law through state liability a myth? An assessment 20 years after Francovich' (2012) 49 Common Market Law Review 1675.
} 
expanding scope has an impact on personal and business relationships, which in turn has affected higher national courts, in particular in the exercise of their judicial roles. ${ }^{46}$

Domestic courts within the EU are not exclusively courts of their Member State. They form an integral component of the EU's decentralised judicial infrastructure with national courts the ordinary courts of the Union. ${ }^{47}$ This view has most recently been articulated by the European Commission, which remarked that national judges 'are also "EU judges" ... ensuring the application of EU law'48 although it has recently and controversially been challenged by the German Constitutional Court. ${ }^{49}$ This interweaving of national legal systems with that of the EU is apparent when we examine the impact of EU legislation on national legal systems. ${ }^{50}$ The data presented here, analysing the frequency of EU law-based arguments before the domestic courts of Scotland and Ireland and the number of appeals identified by this research, indicates that EU law has been embedded as a normal and ordinary part of these jurisdictions' legal traditions. Furthermore, the rise in the number of appeals to the higher courts of Scotland and Ireland over the last five years of the study points to an increasing importance placed by these courts on EU law-based legal arguments.

The impact of Brexit upon the Scottish and Irish legal systems as a result of this embedding of EU law within their legal systems is not yet fully understood, ${ }^{51}$ however the analysis of the subject-matter raised in relation to the case law of each jurisdiction may shine a light on the potential effects. Brexit generates considerable uncertainty and the data discussed here will allow comparison again in a decade as to the extent to which reference to EU law has diminished in the Scottish courts and how reliance on EU law in the Irish courts has changed. For now the post-Brexit position is that in general the body of EU law applicable in the UK up to Brexit is carried over. ${ }^{52}$ There are notable exceptions to this, including the primacy of EU law and the EU Charter on Fundamental Rights, ${ }^{53}$ and legislation is already being readied to replace EU policies. ${ }^{54} \mathrm{UK}$ ministers have controversially been granted powers to amend

\footnotetext{
${ }^{46}$ Much of the literature looks at the operation of the preliminary reference procedure see eg Alter (2001), above n 14; A Stone Sweet and TL Burnell 'The European Court and the national courts: a statistical analysis of preliminary references, 1961-95' (1998) 1 Journal of European Public Policy 5; R Slepcevic 'The judicial enforcement of EU law through national courts: possibilities and limits' (2009) 16(3) Journal of European Public Policy 378; B de Witte et al (eds) National Courts and EU Law - New Issues, Theories and Methods (Cheltenham: Edward Elgar, 2016).

${ }^{47}$ Opinion 1/09 European and Community Patents Court ECLI:EU:C:2011:123, para 80. In contrast to many federalist systems, such as that in the United States, the national courts of the Member States apply Union law within their own respective jurisdictions, entailing a form of co-operative federalism in which domestic courts are entitled and obliged to enforce EU law. See R Schutze European Union Law (Cambridge: Cambridge University Press, $2^{\text {nd }}$ edn, 2018) ch 11.

${ }^{48}$ European Commission 'Rule of Law: European Commission launches infringement procedure to safeguard the independence of judges in Poland' Press Release (Brussels, 29 April 2020), available at https://ec.europa.eu/commission/presscorner/detail/en/ip_20_772. See for example C-619/18 Commission v Poland ECLI:EU:C:2019:531 and C-416/17 Commission v France ECLI:EU:C:2018:811. See also J Zglinski 'The rise of deference: the margin of appreciation and decentralized judicial review in EU free movement law' (2018) 55(5) Common Market Law Review 1347. For an early articulation of this view see I Maher 'National courts as European Community courts' (1994) 14 Legal Studies 226. For an analysis of national courts as decentralised enforcers of EU law see DC Hubner 'The decentralized enforcement of European law: national court decisions on EU directives with and without preliminary reference submissions' (2018) 25(12) Journal of European Public Law 1817 at 1819.

${ }^{49}$ BVerfG, Judgment of the Second Senate of 5 May 2020, 2 BvR 859/15. The case has already generated a huge amount of commentary, see eg the large number of entries on the Verfassungs blog at https://verfassungsblog.de/tag/bverfg/.

${ }^{50}$ See generally T van den Brink The Impact of EU Legislation on National Legal Systems: Towards a New Approach to EU Member State Relations (Cambridge: Cambridge University Press, 2017) p 211.

${ }^{51}$ For a discussion of potential impacts on Ireland see G Hogan 'Laws in common' (2019) 24(1) Journal of the Bar of Ireland 22. For a discussion in the Scottish context see A McHarg 'Brexit and Scots law' (2018) 22 Edinburgh Law Review 107-109.

${ }^{52}$ The European Union (Withdrawal) Act 2018 (UK) repealed the European Communities Act 1972 (UK), the foundational statute for EU law in the UK. The 2018 Act retained the acquis communautaire, ie the body of all legislation, legal acts and court decisions of EU law, including almost all UK laws that resulted from EU membership and its obligations: see ss $1-4$.

${ }^{53}$ Also known as the supremacy doctrine; see s 5 of the European Union (Withdrawal) Act 2018.

${ }^{54}$ See eg The Environment Bill 2020 (UK).
} 
domestic legislation, including retained EU law, to address any deficiencies arising from Brexit. ${ }^{55}$ There is also considerable uncertainty as to the division of competences between the Scottish and the UK parliaments. ${ }^{56}$ Case law of the CJEU from after the Brexit transition period is not binding on UK courts but they can have regard to it. Under the 2018 Act, case law of the CJEU from before Brexit can be binding as to the meaning or effect of any retained EU law or principles, though not on the Supreme Court nor the Scottish High Court of Justiciary when sitting as a court of appeal. ${ }^{57}$

The UK Government has decided, following a consultation process, to introduce Regulations under s 6 of the 2018 Act to also allow lower courts to depart from previous EU case law. ${ }^{58}$ This means the scope of precedent of EU law is uncertain.

\section{Methodology}

The study generated four distinct datasets of cases from all Scottish courts and from Irish Superior courts: Scottish civil cases where EU law arose and Scottish preliminary references in civil and criminal cases; Irish civil cases where EU law arose and Irish preliminary references in civil and criminal cases.

The methodology for this study follows as closely as possible that used by Rodger in his earlier work on the Scottish courts. Hence, for Scotland, data gathered by Rodger in his 2017 work was utilised, revised and updated. The comparative aim of the study meant that the Irish study is as closely aligned as possible with the categorisations created for the first Scottish study. However, absolute alignment of the analytical methodology in each jurisdiction was not possible and differences are set out where they arise. ${ }^{59}$ The focus in this research is on EU law in the civil courts and the impact of EU law on the administration of civil justice, rights and obligations. Accordingly, cases involving the application of EU law in criminal courts, criminal law contexts, ${ }^{60}$ and all case law involving European Arrest Warrants are excluded. ${ }^{61}$ As the study only relates to EU law, cases which related only to the European Convention of Human Rights (ECHR) were excluded, as it forms a separate

\footnotetext{
${ }^{55}$ The European Union (Withdrawal Agreement) Act 2020 (UK), s 3 amending s 8 of the 2018 Act. Such sweeping powers are time limited and are known as Henry VIII powers.

${ }^{56}$ The UK Withdrawal from the European Union (Legal Continuity) (Scotland) Bill (UK) - A reference by the Attorney General and the Advocate General for Scotland [2018] UKSC 64. For an overview see The Law Society of Scotland, The Future Impact and Effect of Brexit on Scots Law and the Scottish Legal System (2019). See also the Internal Market Act and the Scottish Government's Legislative Memorandum to the Bill at https://www.gov.scot/news/internal-market-bill/.

${ }^{57}$ There are some exceptions for the High Court of Justiciary: see Law Society of Scotland, ibid, p 30 and s 6 of the 2018 Act as amended.

${ }^{58}$ The European Union (Withdrawal Agreement) Act 2020 (UK), s 26, amending s 6 of the 2018 Act, see the Government response to the consultation on the departure from retained EU case law by UK courts and tribunals, CP303, October 2020, https://assets.publishing.service.gov.uk/government/uploads/system/uploads/attachment_data/file/926811/departure-eucase-law-uk-courts-tribunals-consultation-response.pdf.

${ }^{59}$ To enable more direct comparison with the Irish data, case law from the Scottish Lands Court and Employment Appeal Tribunal was excluded. For discussions on comparative methodologies in legal studies, and the associated difficulties, see generally G Wilson 'Comparative legal scholarship' in M McConville and WH Chui (eds) Research Methods for Law (Edinburgh: Edinburgh University Press, 2007) p 87; G Samuel 'Comparative law and its methodology' in Research Methods in Law (Oxford: Routledge, $2^{\text {nd }}$ edn, 2018) p 122; L Kestemont Handbook on Legal Methodology: From Objective to Method (Cambridge: Intersentia, 2018) p 36.

${ }^{60}$ This is to keep the study manageable for the purposes of this paper. See for example Hunter $v$ The Caledonian Cheese Co Ltd Stranraer Sheriff Court 19 July 2011, in relation to the Urban Wastewater Treatment (Scotland) Regulations 1994 and Council Directive 79/923/EEC OJ L 281/47 on the quality required of shellfish waters. Cases originating from the Irish Special Criminal Court, Central Criminal Court, and Court of Criminal Appeal have been excluded from the dataset generated.

${ }^{61}$ See Crown Office European Arrest Warrant statistics as at 13 July 2016, https://www.copfs.gov.uk/foi/responses-we-havemade-to-foi-requests/38-responses2016/1373-european-arrest-warrants-13-july-2016-r013208. For Ireland see the Department of Justice and Equality's most recent report published in December 2018, entitled 'Report On the operation of the European Arrest Warrant Act 2003 (as amended) for the year 2017 made to the Houses of the Oireachtas by the Central Authority in the person of the Minister for Justice and Equality pursuant to section 6(6) of the European Arrest Warrant Act 2003', available at http://www.justice.ie/en/JELR/European_Arrest_Warrant_Annual_Report_for_2017.pdf/ Files/European_Arrest_Warrant_Annual_Report_for_2017.pdf. The report notes that in 2017 there were 40 persons returned
} 
legal system to the EU's. ${ }^{62}$ Where EU law was mentioned but was completely irrelevant, the case was excluded for both jurisdictions. ${ }^{63}$

\section{(a) Scotland}

All published judgments by the Scottish civil courts between 2009 and 2018 including the Supreme Court in Scottish appeals were coded according to whether they emanated from the Sheriff Court (Sheriff or Sheriff Principal on appeal), Sheriff Appeal Court, ${ }^{64}$ Court of Session Outer House, ${ }^{65}$ Court of Session Inner House ${ }^{66}$ or the Supreme Court (in Scottish cases) ${ }^{67}$ For the Scottish dataset the initial search was undertaken using Westlaw. ${ }^{68}$ Each case was then briefly reviewed to ascertain whether, on the face of it, it referred to EU law. This general check was complemented by searching the Scottish cases published on Westlaw against a variety of generic EU law search terms, ${ }^{69}$ and the results were also cross-checked against the Scottish Courts website. ${ }^{70}$

\section{(b) Ireland}

Only the civil jurisdiction of the Superior Courts in Ireland are part of the study. ${ }^{71}$ This is because the decisions of the Irish lower courts (Circuit and District Courts) are not normally published or reported. ${ }^{72}$ There are comprehensive reports publicly accessible for the Superior Courts. Judgments for the Irish dataset were coded according to their emanation from the High Court, Court of Appeal, ${ }^{73}$ or the

to Ireland because of European Arrest Warrants, and Ireland returned 60 individuals to other EU Member States via the use of European Arrest Warrants during the same period.

${ }^{62}$ The European Convention on Human Rights (ECHR) is an international convention which predates the establishment of the EU and constitutes a separate legal system. See WA Schabas The European Convention on Human Rights: A Commentary (Oxford: Oxford University Press, 2015) in particular pp 1-10.

${ }^{63}$ See for example in Scotland the Inner House and Supreme Court judgment in 2012 in Imperial Tobacco Ltd, Petitioner [2012] CSIH 9, 2012 SC 297, and [2013] SC (UKSC) 153, 2013 SLT 2 respectively, where there was no mention of EU law, unlike the earlier Outer House judgment.

${ }^{64}$ The Sheriff Appeal Court was introduced by the Courts Reform (Scotland) Act 2014 and assumed jurisdiction in respect of appeals from decisions in the Sheriff Court on 1 January 2016. Cases can only now be appealed to the Court of Session (Inner House) with either the permission of the Sheriff Appeal Court or the Court of Session. See http://www.parliament.scot/ ResearchBriefingsAndFactsheets/S5/SB_16-98_Civil_Justice_-_Civil_Courts_and_Tribunals.pdf.

${ }^{65}$ The Outer House is also a first instance civil court in Scotland; for discussion of the relative competences of the Sheriff Court and Outer House of the Court of Session, and on the Scottish courts generally see StJ Bates et al The Legal System of Scotland (Edinburgh: W Green, 5th edn, 2014).

${ }^{66}$ The Inner House is an appeal court in civil cases in Scotland: see Bates et al, above n 65. See also the Courts Reform (Scotland) Act 2014.

${ }^{67}$ The Supreme Court is the highest civil court in the UK. See Bates et al, above n 65.

${ }^{68}$ There were minor feasibility issues: the first is that not all judgments of the courts are published, although it is unlikely that any case involving the application of EU law would not comprise either a significant point of law or particular public interest; the second is that not all legal disputes involving EU are litigated to the point of a court judgment but we have to simply accept that the research cannot cover cases which are settled or involve mediation or other forms of alternative dispute resolution which are not in the public domain.

${ }^{69}$ Including 'European Union', 'EU', 'European Community', 'EC', 'European Economic Community', 'EEC', 'TFEU', 'TEC', 'Directive', etc.

${ }^{70}$ https://www.gov.scot/publications/civil-justice-statistics-scotland-2017-18/pages/1/.

${ }^{71}$ The Irish superior courts, High Court, Court of Appeal and Supreme Court (the apex court) are set down by Arts 34-37 of the Constitution of Ireland.

${ }^{72}$ There are exceptions to this general rule, notably access to judgments of the District Court are maintained for childcare cases; see Government of Ireland, Access to Court Judgment and Determinations, available at https://www.gov.ie/en/service/ access-court-judgments-and-determinations/. Records for the lower courts cannot be accessed via freedom of information requests. See the Freedom of Information Act, 2014 (Ireland), s 42(a)(I). For a contemporary analysis of the importance of the Irish District Court's role in the Irish criminal law sphere see C O'Nolan The Irish District Court: A Social Portrait (Cork: Cork University Press, 2013).

${ }^{73}$ The Court of Appeal was established by the passing of the Thirty Third Amendment of the Constitution (Court of Appeal) Act 2013 (Ireland) following the passing of a referendum on 4 October 2013. This constitutional amendment 
Supreme Court. The Irish High Court is a court of first instance with full and original jurisdiction and power to determine all matters of law. The Court of Appeal has appellate jurisdiction in respect of all decisions of the High Court, and other courts as prescribed by law. The Supreme Court is the apex court within the Irish state, its decisions are final. For the Irish dataset the initial search was carried out using Bailli.org and, ${ }^{74}$ as in the Scottish case, each judgment was briefly reviewed to ascertain whether it presented an issue of EU law and if it did not, then it was excluded. Results were crosschecked against Justis.com. ${ }^{75}$

\section{(c) Shared methodology}

The research extends to all civil law cases in the above courts of which EU law formed part or was relied on by either party or in the judgment, even where EU law was not a factor in the determination of the particular issue between the parties in dispute, for instance where the case was decided on a procedural issue. Each dataset generated was reviewed, coded, and analysed quantitatively using SPSS. $^{76}$ To identify more subtle trends, frequency analysis was carried out on the EU case law sample $^{77}$ and crosstabulations were made between variables: ${ }^{78}$ (1) courts; (2) years; (3) subject-matter; (4) private law relations; (5) judicial review; (6) claims/defences in EU Law cases; (7) relevance; (8) type of EU legal instruments; and (9) preliminary references.

\section{(1) Courts and (2) EU cases per year}

In addition to recording the court in which a case was heard, the study also recorded the year of each case in order to allow us to map out the change in EU law cases before the domestic courts of both jurisdictions over the ten-year period.

\section{(3) Subject-matter}

This refers to the substantive legal issue(s) at the heart of the dispute which involve EU law. ${ }^{79}$

The categories used were those identified in the earlier Scottish study. The coding of cases was done by undertaking a preliminary reading of the cases to determine the category to which they belonged. At times this proved problematic, as disputes do not fall into neat legal categories; potential overlap occurred particularly between the categories of delict/tort law and discrimination/equality law, or with employment law. ${ }^{80}$ Some categories were merged, eg data protection and intellectual property law, where there was come interconnectedness and little case law; planning law and environmental

was given effect by the Court of Appeal Act 2014 (Ireland) and the Court of Appeal entered operation on 28 October 2014. As such, no data for the Court of Appeal exists prior to October 2014.

${ }^{74}$ http://www.bailii.org/.

${ }^{75}$ https://app.justis.com/.

${ }^{76}$ SPSS 25 was used in the Scottish study while SPSS 24 was used for Ireland. SPSS is the acronym for Statistical Package for the Social Science, a statistical tool which helps to analyse data.

${ }^{77}$ It should be stressed that the term 'frequency' here relates to the case law within the EU law sample and not to levels of litigation before the courts generally.

${ }^{78}$ See F Clegg Simple Statistics, A Course Book for the Social Sciences (Cambridge: Cambridge University Press, 1990); see also C Acton et al SPSS for Social Scientists (Basingstoke: Palgrave Macmillan, 2009).

${ }^{79}$ For example, where the substantive issue in a case related to procedural issues as to the appellant's locus standi, but the issue of standing was tied to the concept of a 'sufficient interest' test due to EU law obligations under the Habitats Directive, the case was assigned to the planning and environmental law category. (See Directive 2011/92/EU on the assessment of the effects of certain public and private projects on the environment [2011] OJ L 26/1.)

${ }^{80}$ Although consistent coding of case law is difficult, the tendency was to code any personal injury damages claims as delict/tort even when they arose in a work context (eg EU health and safety at work provisions in for example Council Directive 89/391/EEC on the introduction of measures to encourage improvements in the safety and health of workers at work [1989] OJ L 183/1 and Council Directive 89/655/EEC concerning the minimum safety and health requirements for the use of work equipment by workers at work [1989] OJ L 393/13), but this category also extended to for example cases involving Regulation (EC) No 261/2004 establishing common rules on compensation and assistance to passengers in the event of denied boarding and of cancellation or long delay of flights [2004] OJ L 46/1, the EU compensation regime for airline 
law where there was interconnectedness. In addition, it should be noted that 'delict' (Scotland) and 'tort' (Ireland) are treated as equivalent categories.

In total there were 20 categories recorded: Agriculture \& Fisheries Law, Citizenship, Competition Law, Consumer Law, Contract \& Commercial Law, Discrimination and Equality Law, Employment Law, Family Law, Free Movement Law, Human Rights Law, Immigration, Asylum \& Refugee Law, IP Law, Planning \& Environmental Law, Private International - Civil \& Commercial Law, Private International - Family \& Children Law, Public Procurement Law, Public, Administrative and Procedural Law, Revenue/Tax Law, State Aid and Tort or Delict.

\section{(4) Private law relationships}

The project sought to assess the extent to which EU law was raised and applied in disputes between private parties, drawing on the work of Leczykiewicz and Weatherill where they explored the extent to which EU law affected private autonomy. ${ }^{81}$ This is to underscore how EU law extends beyond the state.

\section{(5) Judicial review}

Judicial review is the process by which a court reviews a decision, act or failure to act by a public body or other official decision maker. It is only available where other effective remedies have been exhausted and where there is a recognised ground of challenge. ${ }^{82}$ Judicial review proceedings in Scotland in the Court of Session have been the subject of considerable debate, ${ }^{83}$ and the increasing significance of judicial review generally before the Scottish courts has been stressed. ${ }^{84}$ In Ireland, judicial review is enshrined in the Constitution ${ }^{85}$ but despite this longstanding mandate, the superior courts have treated the power cautiously ${ }^{86}$ apart from a 20 -year period of judicial activism from the 1960s when the courts engaged with and articulated the scope of constitutional rights. ${ }^{87}$ Hence the courts have what Cahill and O'Conaill call an 'instinct towards restraint' in relation to judicial review underpinned by the presumption of constitutionality. ${ }^{88}$

\footnotetext{
passenger who suffer delays. whereas cases were only coded as discrimination and equality law where they occurred outside the employment context.

${ }^{81} \mathrm{D}$ Leczykiewicz and S Weatherill (eds) The Involvement of EU Law in Private Law Relationships (Oxford: Oxford University Press, 2013). They define private law relationships as 'a sub-category of legal relationships that are traditionally governed by the area of law referred to as 'private law' (at $\mathrm{p} 2$ ). While the distinction between private and public law has been questioned both at the conceptual and at the normative level, it does form part of the legal traditions of the Member States (albeit to different degrees). On the one hand, we have an area of the law which regulates relationships among individuals or non-public actors, which are conventionally believed to be in a position of equality, and which concerns activities unrelated to the exercise of public power'. See also D Chalmers 'The positioning of EU judicial politics within the United Kingdom' (2000) 23(4) West European Politics 169.

${ }^{82}$ For Scottish Law see Lord Clyde and DJ Edwards Judicial Review (Edinburgh: W Green \& Son, 2000); DJ Edwards 'Thirty years of judicial review in Scotland: the influence of European law' (2015) 4 The Juridical Review 399.

${ }^{83}$ See the Courts Reform (Scotland) Act 2014 (UK); Edwards, above n 82.

${ }^{84}$ See Special Issue of the Juridical Review on judicial review (2015) Issue 4; C McCorkindale et al 'Judicial review at thirty' (2015) 4 The Juridical Review 317, in particular R Reed 'The development of judicial review in Scotland' at 325. See also T Mullen et al Judicial Review in Scotland (Chichester: John Wiley \& Sons, 1996).

${ }^{85}$ Arts 15.4 .2 and 34.3.2.

${ }^{86}$ See eg Maher $v$ Attorney General [1973] IR 140, where the court warns of the importance of the courts not straying into the legislative function. See also State (Keegan) $v$ Stardust Victims' Compensation Tribunal [1986] IR 642 at 658, setting down that the relevant test is whether the challenged decision is unreasonable or irrational.

${ }^{87}$ For a succinct review see M Cahill and S O'Conaill 'Judicial restraint can also undermine constitutional principles: an Irish caution' (2017) 36(2) University of Queensland Law Journal 259. For an analysis with an explicitly EU law focus see A Ryall 'Enforcing the Environmental Impact Assessment Directive in Ireland: evolution of the standard of judicial review' (2018) 7(3) Transnational Environmental Law 515. See generally M de Blacam Judicial Review (Dublin, Bloomsbury Professional, $3^{\text {rd }}$ edn, 2017).

${ }^{88}$ Cahill and O'Conaill, above n 87, at 264 .
} 


\section{(6) Claim or defence}

We coded cases on the basis of whether EU law was raised by the claimant or defence (appellant or respondent in Ireland) ${ }^{89}$ to explore the hypothesis that EU law was primarily used as a sword by claimants. EU membership requires EU laws to be applied as part of the domestic legal order of Member States. ${ }^{90}$ Where EU law creates rights for individuals (and not every provision of EU law falls into this category) these rights take effect not only as part of the domestic system, but take primacy over domestic law where conflict arises. ${ }^{91}$ The consequence being that if you can show, in certain situations, that EU law applies to your case you have 'the winning point'. ${ }^{92}$ This is of particular importance to commercial disputes, for example. ${ }^{93}$ However, the ability of litigants to have their EU law rights vindicated is contingent on a number of factors: their own organisational capacities, access to courts generally, and significantly national courts' interpretation of EU law (subject of course to CJEU jurisprudence) is likely to determine the possibility of enforcing European law through litigation. ${ }^{94}$ Therefore national judges may also be acting as swords and shields, shielding national legislation from the CJEU or alternatively acting as a sword and fostering EU integration. ${ }^{95}$

\section{(7) Relevance}

We coded the cases as 'determinative/dispositive'; 'relevant/considered' and 'irrelevant' to allow us to try and consider the extent to which the EU law determination was significant in the coded judgments. The classification of cases under these various categories is both difficult, problematic and a matter of judgement. The 'determinative/dispositive' category is intended to denote case law where the EU rule or provision was a key factor in the outcome of the judgment and was central to the resolution of the dispute, and this inevitably encompassed the majority of the judgments. The second category of 'relevant/considered' indicates case law where the outcome of the judgment did not depend on an EU law provision, although it formed an important aspect of the context or background in the case. ${ }^{96}$ The third category of 'irrelevant' connotes cases where EU law was raised but was deemed to be irrelevant or the case did not fall at all within the scope of the provision. ${ }^{97}$

\section{(8) Legal instruments}

There are a range of EU instruments that were raised in proceedings in both jurisdictions: Treaty; Regulation; Directive; Decision; Charter of Fundamental Rights; General principles of EU

\footnotetext{
${ }^{89}$ And in some cases this is difficult where EU law merely sets the context rather than being specifically relied upon.

${ }^{90}$ The doctrine of direct effect: C-26/62 van Gend en Loos [1963] ECR 1. See generally Chalmers et al, above $\mathrm{n} 40$, ch 7.

${ }^{91} \mathrm{R}$ D'Sa 'Protection of rights in European Community law: a sword and shield?' (1997) 22(3) Commonwealth Law Bulletin 1266.

${ }^{92}$ Ibid.

${ }^{93}$ Ibid, at 1267.

${ }^{94} \mathrm{R}$ Slepcevic 'The judicial enforcement of EU law through national courts: possibilities and limits' (2009) 16(3) Journal of European Public Policy 378.

${ }^{95}$ See generally A Obermaier 'The national judiciary - sword of European Court of Justice rulings: the example of the Kohll/Decker jurisprudence' (2008) 14 European Law Journal 735.

${ }^{96}$ This category included cases such as Miller v Sabre Insurance Co Ltd [2010] CSOH 139, 2010 GWD 38-774, see above re success, where the relevant EU law provision formed the background framework or context for the specific issue; and also some cases such as MacEchern $v$ Scottish Ministers [2011] CSOH 135, 2011 GWD 28-626, involving consideration of various EU directives on health and safety at work in respect of a claim by a forestry worker, but the specific outcome was a proof before answer and therefore the case was coded as relevant/considered rather than determinative or dispositive. For Ireland see King v Minister for Finance \& Another [2010] IEHC 307, where Directive 76/207/EEC on the implementation of the principle of equal treatment for men and women [1976] OJ L 39/40 formed the background of the claim, but the case centred around a claim of error of law on the part of the Labour Court.

${ }^{97}$ The irrelevant code was utilised for instance in Docherty $v$ Secretary of State for Business, Innovation and Skills [2018] $\mathrm{CSOH}$ 25. For an Irish example see B \& Others v Minister for Justice, Equality and Law Reform [2010] IEHC 296. There are potential overlaps between the categories and between the irrelevant category here and some of the cases which were excluded as being of marginal EU law relevance.
} 
law $^{98}$; soft law ${ }^{99}$; a combination; and Other. The legal instrument at issue in each case was coded based on a determination of the central EU legal provision at issue in the cases, and where there was more than one EU legal instrument which could be considered as the primary EU law instrument at issue, the cases were coded as a 'combination'.

\section{(9) Preliminary references}

Due to the importance of the preliminary reference procedure for the dialogue between national courts and the CJEU, a separate dataset on all preliminary rulings referred to the CJEU from the Scottish and Irish courts was also generated. Using the data available on the CJEU's own website and by specifically searching for references from both Ireland and Scotland, including the urgent preliminary reference procedure, references made by the Scottish and Irish courts were identified. Two datasets were created for this analysis, one for each jurisdiction, each of which was separate from the datasets created to examine EU law before the respective domestic courts of Scotland and Ireland. The datasets include preliminary references made by the domestic courts and tribunals of each jurisdiction, regardless of whether or not a ruling was given by the CJEU or whether the reference was later withdrawn. Because this dataset was small, it was possible to include both civil and criminal cases.

\section{Results and analysis}

\section{(a) Courts}

There were 288 cases in the main Scottish courts (including the Supreme Court sitting in Scottish cases) from 1 January 2009 to 31 December 2018. There were 678 cases for the Irish Superior Courts in the same decade. ${ }^{100}$

\section{Analysis}

The much larger number of cases in the Irish system is one of the significant findings of the study. The fact that Ireland is a single, unitary state may be suggested as one rationale for more cases within the Irish courts. However, Scotland has a slightly larger population and the availability of actions and remedies against all emanations of the state (Scottish and UK-wide) before the Scottish courts suggests the nature of Scotland as a devolved region within the UK is less significant as a factor in determining the number of EU law-based cases before the Scottish courts. Given that EU law is a core subject in all Scottish University qualifying LLB degree programs and all Irish University law degrees, it is unlikely that there is a comparative lack of awareness in the Scottish legal profession about the scope of European law. ${ }^{101}$ Nonetheless, anecdotal evidence from leading practitioners has suggested that it

\footnotetext{
${ }^{98}$ These are developed by the CJEU; see generally T Tridimas The General Principles of EU Law (Oxford: Oxford University Press, $3^{\text {rd }}$ edn, 2020).

${ }^{99}$ Art 288 Treaty on the Functioning of the European Union. Regulations are directly applicable. Directives are binding as to outcome. Decisions are addressed to individuals. Recommendations and Opinions are listed in Art 288 Treaty on the Functioning of the European Union but a wide range of soft law measures can also be found. Soft laws are rules of conduct which, in principle, have no legally binding force but which nevertheless may have practical effects, see F Snyder 'The effectiveness of European Community law: institutions, processes, tools and techniques' (1993) 56 Modern Law Review 64.

${ }^{100}$ Note that these figures include some legal disputes where there were multiple hearings and judgments as a result of: (1) appeals where there have been judgments at different court levels and each has been included; (2) cases where there have been multiple judgments in relation to distinct aspects of the dispute, eg procedural and substantive aspects.

${ }^{101}$ It is not clear why there might be less awareness of EU law among members of the Scottish Bar, as EU law has been a core subject in all Scottish university law qualifying LLB degree programmes since the late 1980s. It has been suggested that studying EU law as a 'separate' subject may constitute a partial explanation, although this fails to account for the (increasingly) significant incorporation of EU law material in a range of other Law School core and elective classes over the last 30 years, for example competition law. Nonetheless, there has been very little competition law case law and jurisprudence in the Scottish courts, and the established routes in the UK are to litigate in the High Court or the Competition Appeal Tribunal. See eg B Rodger 'Private enforcement in the UK, collective redress for consumers' in B Rodger et al (eds) Twenty Years of Modern UK Competition Law (Oxford, Oxford University Press, forthcoming). Maher and Riordan confirmed via communication with the Heads of all Irish Law Schools that the study of EU law is a requirement in all Irish Universities.
} 
may reflect the culture of legal practice in Scotland and the resistance to, and slow adaptation to, less traditional forms of legal argumentation. ${ }^{102}$

\section{(b) EU cases per year}

For Scotland, the downward trend in EU law cases before the Scottish courts observable in the 20142015 period remains consistent in the 2016-2018 period. In the Irish data the opposite trend can be observed overall, with yearly increases in the number of EU law cases appearing before the Irish Superior Courts between 2009-2018. This is all the more significant given there were significant decreases in EU law-related cases in some years, eg in 2014 (25.3\% decrease on 2013) and 2018 (36.7\% decrease on 2017) and the overall downward trend in the number of cases before the Irish Superior Courts between 2013 and 2018 (12.45\% decrease). ${ }^{103}$

\section{Analysis}

The earlier research on Scottish EU case law had demonstrated a general upward trend over the 40 years, with a slight downturn in 2014 and 2015. This trend was also observable in the period running from 2016 to 2018. It is unlikely that this is any direct result of the Brexit vote and may be more likely a reflection of the lower number of civil cases generally in the Scottish courts, ${ }^{104}$ but there is no clear explanation for this result. In the Irish data, however, the opposite trend appears to be occurring, with a significant increase in the number of cases litigated in the Irish courts where EU law was relevant. A possible factor contributing to the increase in EU law-related litigation in the Irish Superior Courts might be the increased levels of funding allocated for the provision of legal aid in Ireland following the economic downturn in $2009 .{ }^{105}$ Finally, while this indicates that the caseload of the Irish courts is decreasing, the number of cases in which EU law is raised before the court has increased overall.

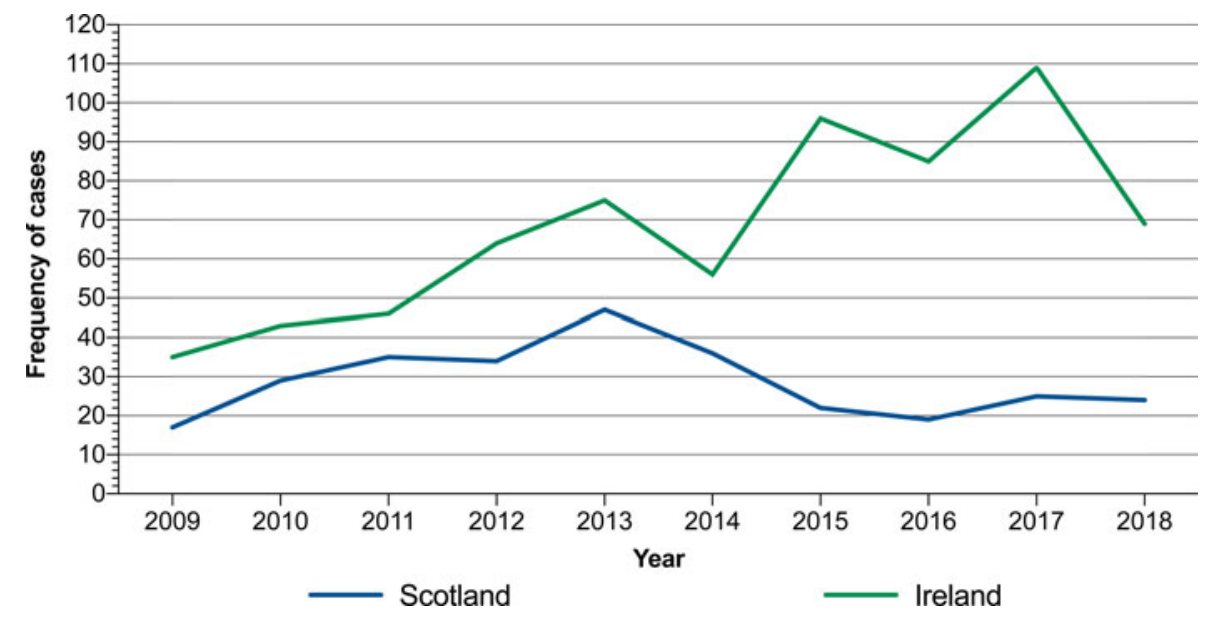

\footnotetext{
${ }^{102}$ Discussions with leading advocates at the Scottish Bar, including a member of AGEUL, a group of EU law advocates at the Bar.

${ }^{103}$ See the Irish Court Service's Annual Reports for 2013 and 2018.

${ }^{104}$ It should be noted that there was a considerable decrease overall in the number of Scottish civil cases. The trend has been bucked slightly by the Civil Justice Statistics in Scotland 2017-18 released on 2 April 2019, which identified a rise in cases initiated across the Sheriff Courts and Court of Session in Scotland by $10 \%$ (only the second increase in 10 years) to 81,200 civil cases initiated. See https:/www.gov.scot/publications/civil-justice-statistics-scotland-2017-18/. Nonetheless, per p 41 there has been a 57\% and 36\% decrease in the number of civil cases initiated and disposed of respectively since $2008 / 09$.

${ }^{105}$ According to data collected by the Council of Europe's European Commission for the efficiency of justice (CEPEJ), legal aid funding in Ireland increased between 2010-2016 with its budget in the latter year in excess of $€ 113$ million, the third highest in countries surveyed: see https://www.coe.int/en/web/cepej/home. Efforts to map growth in ADR is hampered as data is very limited.
} 


\section{(c) Subject-matter}

In both instances, the most frequent case law concerns immigration, asylum and refugee law. There were 48 cases in Scotland ( $16.7 \%$ of the total), a significant increase compared to the $7.9 \%$ over the earlier 40 -year period researched. In Ireland 145 cases $(21.4 \%$ of the total) were also in that category. This was followed in both jurisdictions by planning and environmental law which in Ireland accounted for $16.5 \%$ of cases and in Scotland for $12.1 \%$ of cases. $10.1 \%$ (29) of cases identified in Scotland related to public procurement laws, however this number was significantly lower in Ireland at $3.4 \%(23)$ over the period studied. ${ }^{106}$

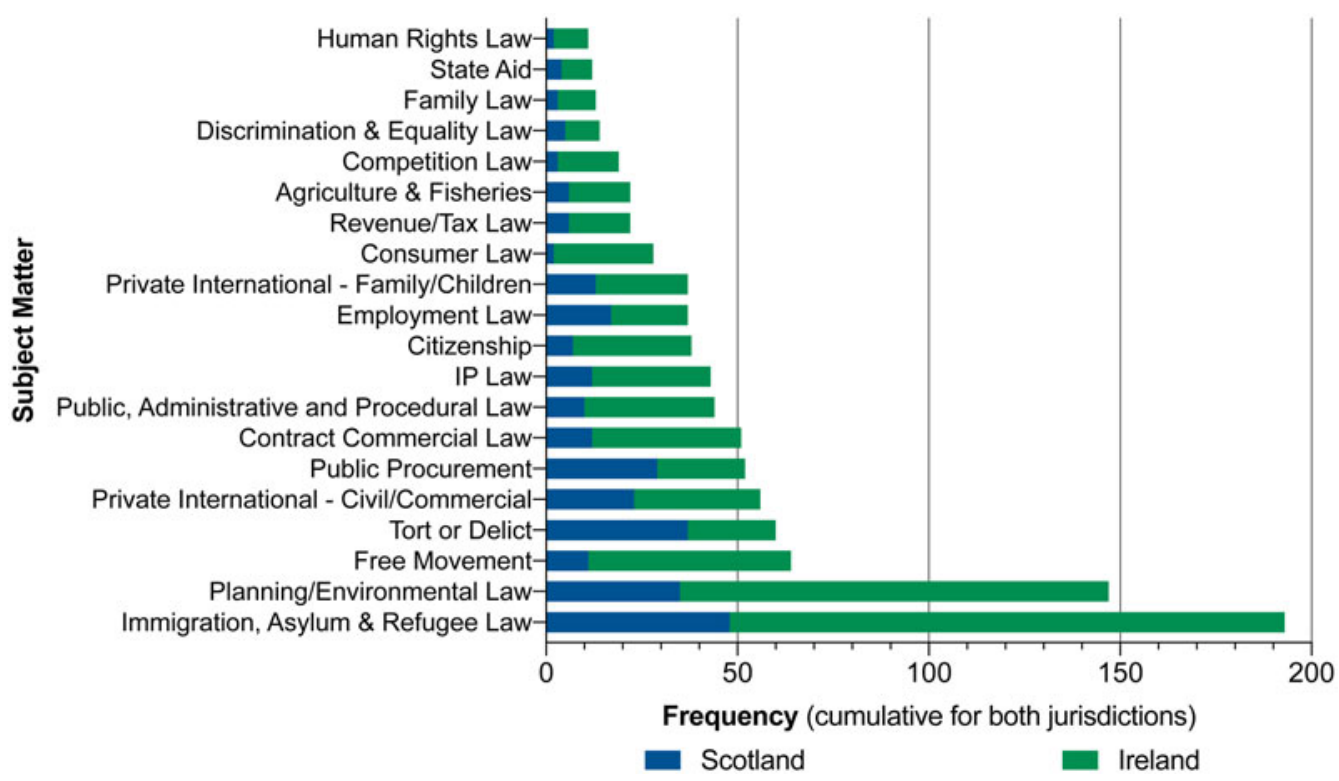

In Scotland, delict accounted for $12.84 \%$ of cases, with private international law standing at $12.5 \%$ collectively (civil \& commercial law at $8 \%$ and family and children law at $4.5 \%$ ).

In Ireland tort law accounted for $3.4 \%$ of cases identified, and private international law stood at a total of $8.4 \%$ (4.9\% civil \& commercial and $3.5 \%$ family \& children respectively).

\section{Analysis}

In both instances EU law was most commonly raised and applied in Immigration, Asylum and Refugee Law indicating a high degree of reliance on EU law, via the Dublin Regulations, for the resolution of international protection applications. ${ }^{107}$ The UK will leave the Common European Asylum

\footnotetext{
${ }^{106}$ By March 2018 Scotland had over 500 live contracts worth $£ 4.7$ billion, 60\% of which are SMEs. See Scottish Government procurement Annual report 2018, available at https://www.gov.scot/publications/scottish-government-procurement-annual-report-2018/pages/5/. The most recent figures for Ireland are for 2016 and report $€ 4.723$ billion in contracts, with 53\% of contracts with SMEs: see the Office of Government Procurement, Public Service Spend and Tendering Analysis Report 2016, published 17 December 2018, available at https://ogp.gov.ie/public-service-spend-and-tendering-analysisreport-for-2016. While spending in Ireland and Scotland is therefore similar, there is a higher percentage of awards given to SMEs in Scotland than Ireland. However, this does not fully explain the discrepancies in public procurement litigation between the two jurisdictions and without the publication of more recent and up-to-date reports it is difficult to explore the primary causes of this.

${ }^{107}$ The Dublin Regulations normalise and harmonise the objective criteria used to determine the Member State responsible for examining an asylum application within the EU: see Dublin II Regulation, Regulation No 343/2003 of 18 February 2003 OJ L050/25; Regulation 343/2003 was superseded by the Dublin III Regulation, Regulation No 604/2013 of 26 June 2013 OJ L180/31
} 
System after Brexit, marking a key change in this area of the law for Scotland after the transition period. ${ }^{108}$ An additional cross-tabulation of the use of the Charter of Fundamental Rights and Freedoms with the subject-matter of EU law before the Irish courts demonstrates that the Charter is most frequently raised in conjunction with human rights based claims, followed closely by public, administrative and procedural law issues. However, overall this pattern accounts for only 9 cases where the Charter alone was relied on, indicating that it has not, in the Irish context, had a significant impact on litigation. ${ }^{109}$

The predominance of disputes involving state emanations is demonstrated by the ongoing significance of cases relating to planning and environmental law. Reid has noted that Brexit has raised a major issue of constitutional contention between the UK and Scottish Governments over powers returning from Brussels and how they are to be exercised by the state, particularly in the area of environmental standards and protections. ${ }^{110}$ Howarth correctly notes that this retention of EU substantive legal rules, including environmental rules, presupposes the existence of corresponding internal governance structures to oversee their implementation within the domestic system. ${ }^{111}$ This may pose challenges for the maintenance of environmental protection standards within Scotland post-Brexit, given the reliance on EU-based environmental rights by litigants and the high number of cases litigated as indicated by the data. ${ }^{112}$ There are also significant levels of EU case law primarily involving private law disputes in both jurisdictions. Crosstabulation between years and subject matter revealed no significant trends in either jurisdiction other than a decreasing frequency in delict case law in Scotland. Despite the slow shift across the EU from a purely public enforcement competition law enforcement model to a system where private enforcement plays a more significant role, ${ }^{113}$ there is as yet little evidence of a surge in competition law-related litigation in this study, in comparison with for example the case law of the English and Welsh courts. ${ }^{114}$

\footnotetext{
${ }^{108}$ See House of Lords, European Union Committee 48th Report of Session 2017-19 HL Paper 428 Brexit: refugee protection and asylum policy 11 October $2019 \mathrm{ch} 3$; M den Heijer 'Remedies in the Dublin Regulation: Ghezelbash and Karim' (2017) 54(3) Common Market Law Review 860; C Yeo and S Reardon-Smith 'The impact of Brexit on UK asylum law' (2018) 32(2) Free Movement Blog, available at https://www.freemovement.org.uk/Brexit-and-borders-schengen-frontexand-the-uk/.

${ }^{109}$ Similarly the Charter alone has been relied on in only two EU law cases in the Scottish courts dataset.

${ }^{110}$ C Reid 'Brexit: a view from Scotland' (2018) 30(2-3) Environmental Law and Management 67; C Reid et al Scotland: Challenges and Opportunities for Post-Brexit Environmental Governance (London: UK in a Changing Europe, 2018).

${ }^{111} \mathrm{~W}$ Howarth 'Brexit and environmental law: the layers of the onion' (2018) 30(2-3) Environmental Law and Management 46 at 48. Scotland has committed to maintaining EU standards after Brexit: see The Environment (EU Exit) (Scotland) (Amendment etc) Regulations 2019 and Scottish Government Press Release 'Protecting the environment after Brexit' 4 October 2019 https://www.gov.scot/news/protecting-the-environment-after-brexit/. See also s 16 of the European Union (Withdrawal) Act 2018 (UK).

${ }^{112}$ Similarly, as the UK will no longer be bound by the EU's common environmental frameworks, Ireland may find it difficult to take actions against the UK where activities within its borders are having a negative impact on its environment and habitats due to the weaker enforcement mechanisms which exist in international law. For example, actions for decisions taken by Ireland against the UK via the Aarhus Convention's Compliance Committee post-Brexit will lack the weight of legal force enjoyed by the CJEU. It is important to note, however, that Northern Ireland stands apart from rest of the UK in this regard as, following the ratification of the withdrawal agreement by the UK, Art 11 of the revised protocol on Ireland and Northern Ireland commits the UK to maintaining 'the necessary conditions for continued North-South cooperation, including in the areas of environment'. See the Agreement on the withdrawal of the United Kingdom of Great Britain and Northern Ireland from the European Union and the European Atomic Energy Community [2019] OJ C 66I and specifically the Protocol on Ireland/Northern Ireland.

${ }^{113}$ See for instance B Rodger et al The EU Antitrust Damages Directive, Transposition in the Member States (Oxford: Oxford University Press, 2018).

${ }^{114}$ See B Rodger 'UK' in Rodger et al, above n 113.
} 


\section{(d) Private law relationships}

Less than half of the Scottish cases (129 or 44.8\%) and just over one third of Irish cases (249 or 36.7\%), concerned private law relationships. These figures are based on the frequency of EU law cases in certain subjects, notably delict and private international law and employment law.

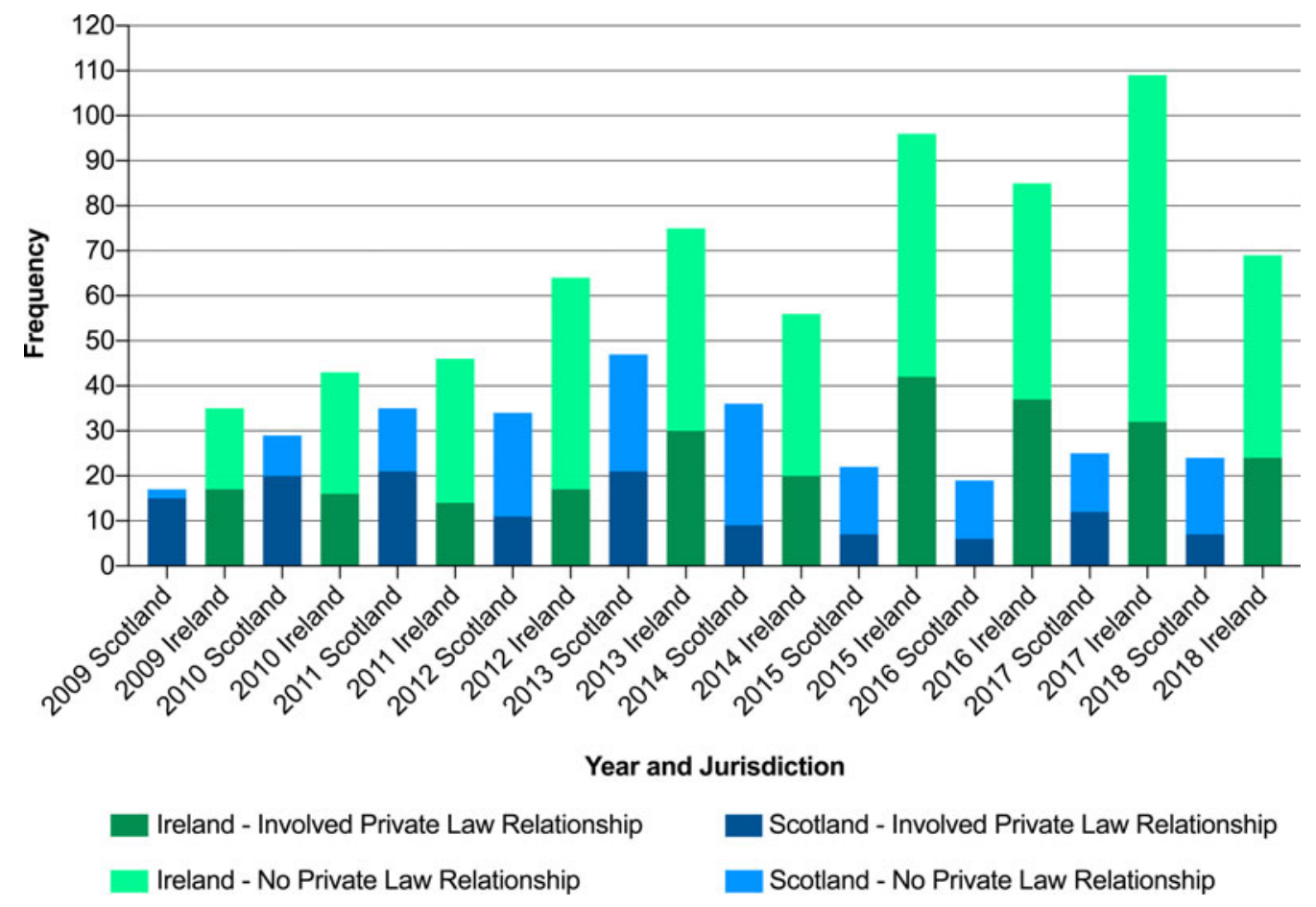

\section{Analysis}

The data supports the thesis that EU law is significant for the decision making of national courts in areas of private law, which traditionally were governed exclusively by domestic law.

While EU law has made major inroads into private relationships, it is noteworthy that the number of cases in this category for Scotland halved in the decade under review. EU law is of diminishing significance, with a clear reduction in cases. This can partly be explained by the reduction in civil law cases generally in the Scottish courts. In Ireland the case law is more evenly spread throughout the decade. EU law is of significance in both the private and public law spheres. The relative reduction in private relationship cases is in part explained by the growth in recent years of cases concerning migration, asylum and refugee law and environmental law. Thus, it is not necessarily that EU law is less relevant for private law relationships but that there has been a growth of cases against the state in these two fields.

\section{(e) Judicial review}

Both jurisdictions have a significant minority of judicial review proceedings with an EU law dimension. In Ireland there were 270 (39.8\%) cases, and Scotland 33\% (though the total number is lower at 95 cases). 


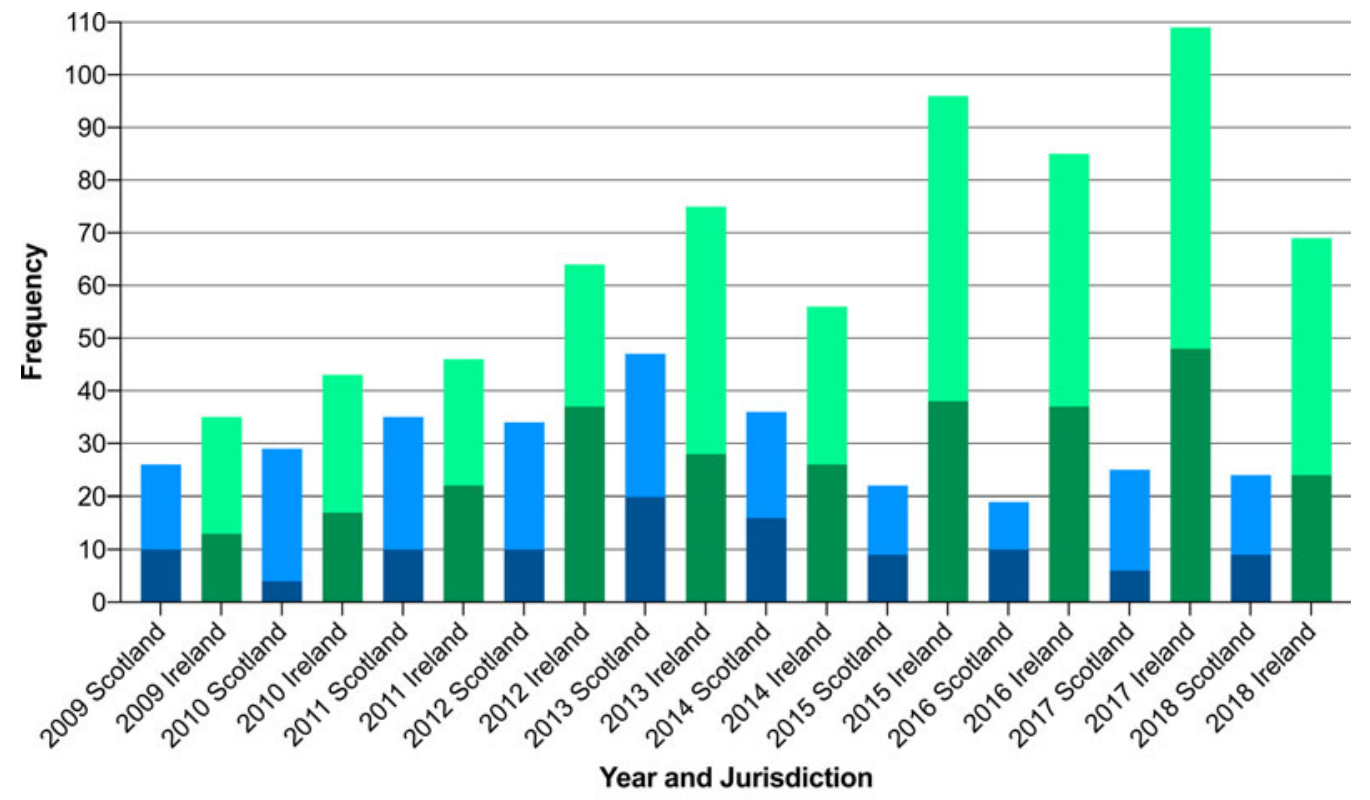

Ireland - Involved Judicial Review Action

Ireland - No Judicial Review Action
Scotland - Involved Judicial Review Action

Scotland - No Judicial Review Action

\section{Analysis}

Judicial review proceedings in Scotland constituted a much greater percentage of all case law involving EU law in 2009-2018 than in any earlier period. ${ }^{115}$ Nonetheless, this also reflects a much broader resort to judicial review in Scotland in recent years, ${ }^{116}$ and indeed the EU component of the overall judicial review caseload of the Court of Session is relatively low given the average of 303 judicial review cases per year in the court over the years 2008-2014. ${ }^{117}$ The number of disposals in judicial review cases in Scotland stood at 483 in 2016/17, an increase by $129 \%$ since 2008/09, ${ }^{118}$ although it should also be noted that only 357 judicial review actions were initiated in total in the Scottish courts in 2017/18. ${ }^{119}$

Judicial review is expansive in Ireland given the 'full original jurisdiction in and power to determine all matters and questions whether of law or fact, civil or criminal' with which the High Court is invested. ${ }^{120}$ This expansive power points towards the comparatively high numbers of judicial review

\footnotetext{
${ }^{115}$ See Edwards, above n 82. See also B Rodger 'The application of EU law by the Scottish courts: an analysis of case-law trends over forty years' (2017) Juridical Review 59.

${ }^{116}$ See A Page 'The judicial review caseload: an Anglo-Scottish comparison' (2015) 4 The Juridical Review 337. See https:// www.gov.scot/publications/civil-justice-statistics-scotland-2016-17/pages/40/.

${ }^{117}$ See Page, above n 116, at 345-346.

${ }^{118}$ https://www.gov.scot/publications/civil-justice-statistics-scotland-2016-17/pages/40/.

${ }^{119}$ https://www.gov.scot/publications/civil-justice-statistics-scotland-2017-18/.

${ }^{120}$ The Constitution of Ireland, Art 34(3)(1) and Art 34(3)(2).
} 
cases within the Irish courts compared to the Scottish courts. More generally, data for the number of judicial review cases incoming and resolved by the Irish superior courts is sparse, with relatively consistent data only available in relation to the Irish High Court. In 2017 there were 961 incoming judicial review proceedings before the High Court, ${ }^{121}$ increasing to 1076 in 2018 (an $11.9 \%$ increase). ${ }^{122}$ Overall there was a decline of $18.2 \%$ in judicial review cases between 2009 and 2018 in the High Court. $^{123}$

In relation to EU judicial review case law, the data for Scotland and Ireland reflect a broadly similar upward trend. All the citizenship and free movement EU law-related case law and the vast majority (41 of 48 cases in Scotland and 113 of 145 in Ireland) of the immigration and asylum/refugee case law involved judicial review petitions. EU law is significant in reviewing the actions of the state and the relationship between states and their citizens.

\section{(f) Claim or defence}

Of the Scottish EU cases, 92.4\% (266) involved EU law being raised by the claimant. In Ireland EU law was raised by the appellant in $86.3 \%$ (585) of all cases assessed. EU law was raised by the applicant most frequently before the Irish courts in immigration, asylum and refugee law cases: 141 of a total 145 recorded cases. In the 'Private International Law - Civil / Commercial' category EU law was raised to a significant degree by the defender/respondent to the case (7 cases in Scotland and 16 in Ireland)

\section{Analysis}

This data demonstrates, as D'Sa argued as far back as 1997, that EU law can act as both a sword and a shield for the protection of rights, providing tangible protection to individuals within their domestic legal systems that they would not be afforded if not for the presence of EU law within the field. ${ }^{124}$ Furthermore, that appellants raised EU law in $86.3 \%$ of cases identified for Ireland demonstrates the importance of EU law as a sword, that is an action against another party, within the domestic legal system, and this was demonstrated to an even greater extent before the Scottish courts. The degree to which applicants in immigration, asylum and refugee law cases raised EU law indicates its importance as both a source of rights and a defence against the state in the Irish context. Only in the context of the 'Private International Law - Civil / Commercial' category was there a significant number of cases involving EU law raised by the defender/respondent in both legal systems.

\section{(g) Relevance}

In Scotland EU law was determinative in $69.1 \%$ of cases; in Ireland this figure stood at $70.5 \%$ of cases (a $1.4 \%$ difference). EU law was considered in $26.4 \%$ of Scottish cases and $21.2 \%$ of Irish cases. EU law was irrelevant to $4.5 \%$ of cases raising EU law in Scotland and $8.3 \%$ of cases in Ireland.

\footnotetext{
${ }^{121}$ Court Service Annual Report 2017 p 54.

${ }^{122} 382$ judicial review cases were resolved by the High Court in 2017 and 467 in 2018: Court Service Annual Report 2018 pp 56-57. Of the 1076 incoming cases in 2018, half related to asylum law (539).

${ }^{123}$ Court Service Annual Report 2009 p 45. High Court figures for judicial review cases disposed of by the court during 2009 are not available.

${ }^{124} \mathrm{D}$ 'Sa, above n 91
} 


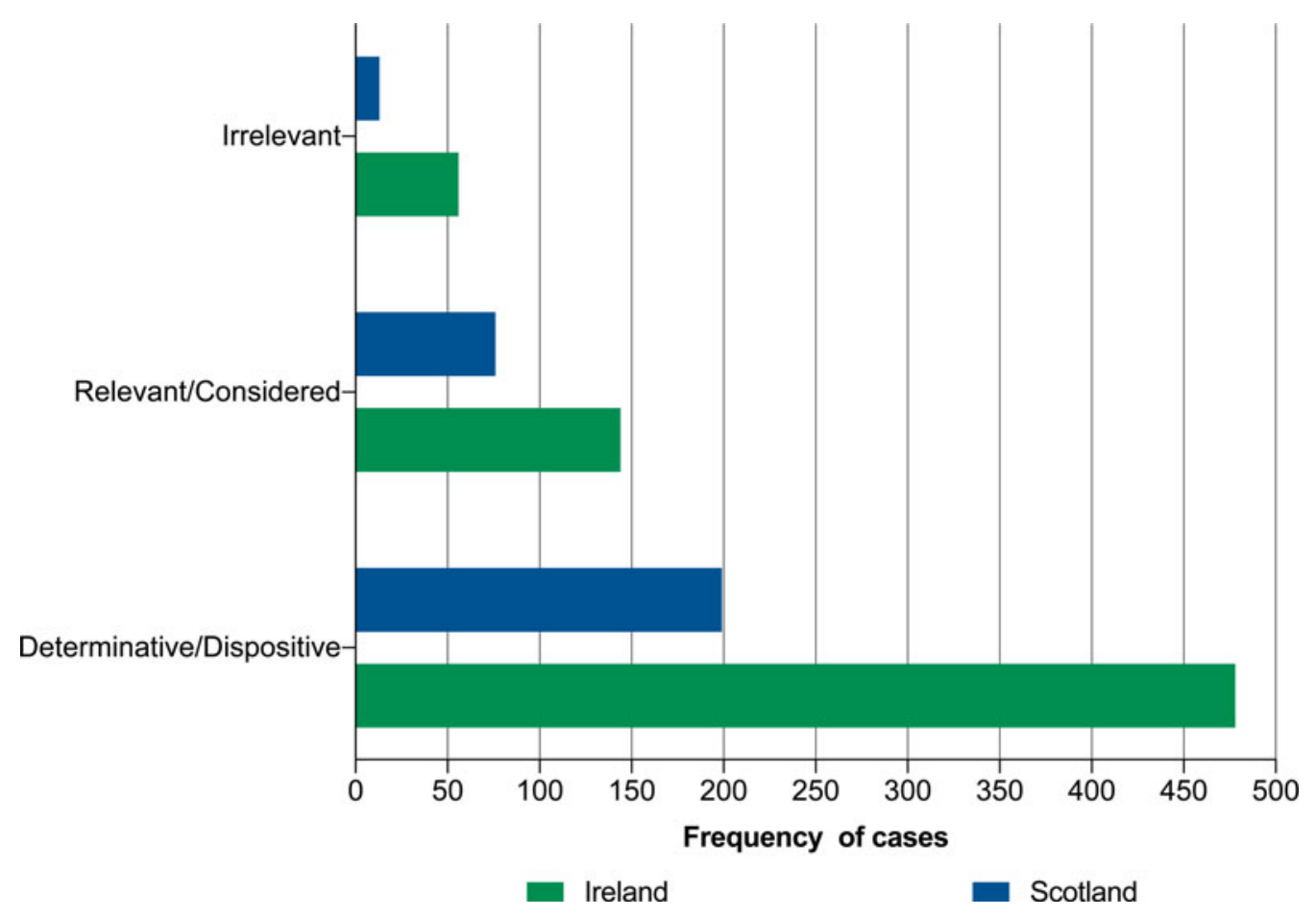

\section{Analysis}

The data demonstrates striking similarities between the Scottish and Irish courts regarding how determinative EU law is, when raised, to the outcome of cases. This suggests that in both jurisdictions EU law is most likely to be raised where it is central to the outcome of the case, or at least is highly relevant. Furthermore, the high percentage of cases from both Scotland and Ireland which identified EU law as determinative to the outcome of a case, may also be indicative of both an increasing awareness and effective deployment of EU law by claimants in the litigation process.

\section{(h) Legal instruments}

In Scotland, $58.3 \%$ of all cases involved directives, and in Ireland $62.2 \%$ of cases involved directives, with regulations following at $18.8 \%$ in Scotland and $16.9 \%$ in Ireland. ${ }^{125}$ The application of a treaty provision was at issue in 36 cases (12.5\%) in Scotland and 61 cases (9\%) in Ireland, ${ }^{126}$ primarily related to citizenship, public law (admin and procedural) and competition law cases for both jurisdictions.

\footnotetext{
${ }^{125}$ These figures tally with Rodger's findings in his earlier study: see Rodger, above $\mathrm{n} 6$, at 83 .

${ }^{126}$ The 'combination' category frequently involved the combined consideration/application of Treaty and Directive provisions, particularly in employment cases.
} 


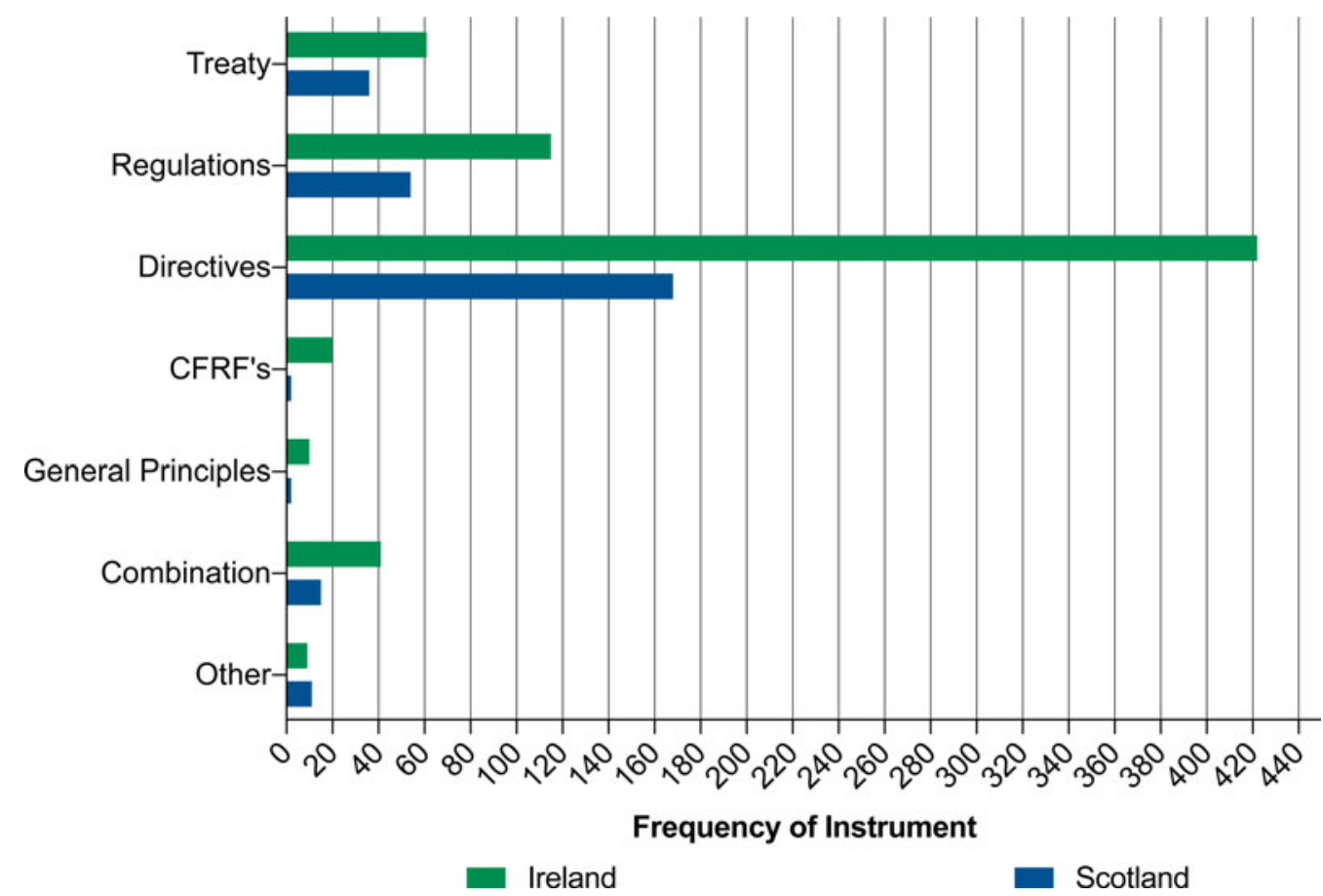

\section{Analysis}

Both the Scottish and Irish case law indicate that the most commonly applied EU instruments are directives. The predominance of directives in the data is perhaps unsurprising given that directives are the most common EU legal instrument, followed by regulations, as the data again demonstrates. ${ }^{127}$ Directives are generalised pieces of legislation which set out policy goals to be attained by the Member States and are binding as to the result to be achieved. ${ }^{128}$ They grant national policy-makers the freedom to select the most appropriate method of attaining these goals within the domestic system. ${ }^{129}$ This decentralised method of legislative implementation with Member States, as Hubner has argued, leaves more room for manoeuvre in implementation and can lead to more complex regulatory questions arising before national courts as to the scope and application of directives, and additionally increases the likelihood of references being made to the CJEU as to the interpretation and validity of such acts. ${ }^{130}$ Therefore, EU legislative instruments such as regulations, as the data appears to indicate, are less likely to be raised in legal proceedings as they leave considerably less room for differences of interpretation given their direct applicability to objectively determined situations. ${ }^{131}$

The comparatively low use of EU Treaties in litigation arguably reflects their role as 'framework treaties' which establish procedures and governance structures that empower EU Institutions, such as the Parliament, to make secondary EU laws which carry out the substantive task of securing the

\footnotetext{
${ }^{127}$ D Chalmers et al European Union Law (Cambridge: Cambridge University Press, $4^{\text {th }}$ edn, 2019) pp 113-116.

${ }^{128}$ Ibid, p 114.

${ }^{129}$ A Zhelyazkova et al 'When practice goes beyond legislators' expectations: analysis of practical implementation exceeding legal compliance with EU directives' (2018) 56(3) Journal of Common Market Studies 520 at 524.

${ }^{130}$ DC Hubner 'The decentralised enforcement of European law: national court decisions on EU directives with and without preliminary reference submissions' (2018) 25(12) Journal of European Public Policy 1817 at 1826.

${ }^{131}$ Chalmers et al, above n 127, p 114.
} 
treaties' objectives by regulating activities within, and between, Member States via the transposing of these goals into the regulations and directives which contain them. ${ }^{132}$ The 'Other' category of rules essentially encompasses conventions, primarily the Brussels Convention where there have been fewer cases arising in the more recent period given that the Convention was superseded by Regulation 44/2001 and its successor Regulation 1215/2012.

\section{(i) Preliminary references to the Court of Justice}

There were five references from the relevant Scottish courts to the CJEU and five rulings in the tenyear period ${ }^{133}$ out of $288 \mathrm{EU}$ cases $(1.7 \%)$. The Scottish references were on tax (two cases concerning VAT and interpretation of Directive 77/388/EEC); ${ }^{134}$ CAP payments (interpretation of Regulation 795/ 2004); ${ }^{135}$ minimum pricing of alcohol in the context of free movement of goods; ${ }^{136}$ and a reference on Article 50 TEU in the context of Brexit. ${ }^{137}$ Only the latter two cases were referred from the Supreme Court in appeals from the lower Scottish courts.

There were a total of 64 references from courts (58) and tribunals (6) ${ }^{138}$ in the Irish jurisdiction over the ten-year period of the study. Of these, seven were referred via the urgent preliminary reference procedure. $^{139} 21$ were made by the Supreme Court, 9 by the Court of Appeal, and 28 by the High Court. Civil law issues accounted for 47 cases referred, with the remaining 11 stemming from criminal law issues.

\section{Analysis}

Preliminary reference requests constitute the single most important mechanism connecting national courts with the CJEU, setting in train a dialogue between them and allowing national courts to raise questions of interpretation with the CJEU. ${ }^{140}$ The difference in practice between the two jurisdictions ${ }^{141}$ may

\footnotetext{
${ }^{132}$ Chalmers et al, above n 127, p 113. As noted by Davies, the EU's governance structure is highly constitutionalised via the treaties which include not only legal principals but also a broad array of policy goals and embedded governance frameworks: see G Davies 'Does the Court of Justice own the Treaties? Interpretative pluralism as a solution to overconstitutionalising' (2018) 24 European Law Journal 360-364.

${ }^{133}$ In the earlier research to the end of 2015, the Scottish courts had made a total of 12 references (though 4 were in a criminal law context) see Rodger, above $\mathrm{n} 6$.

${ }^{134}$ Cases C-270/09 and 277/09 MacDonald Resorts Ltd v Revenue and Customs Commissioners [2011] STC 412 and Revenue and Customs Commissioners v RBS Deutschland Holdings GmbH [2011] STC 345 respectively.

${ }^{135}$ Case C-335/13 Feakins $v$ The Scottish Ministers 2013 SLCR 52.

${ }^{136}$ Case C-333/14 Scotch Whisky Association and Others $v$ Lord Advocate [2016] 2 CMLR 27.

${ }^{137}$ Case C-621/18 Wightman \& Others $v$ Secretary of State for Exiting the EU EU:C:2018:999.

${ }^{138}$ Data accessed via the CJEU's case law search form (see http://curia.europa.eu/juris/recherche.jsf?language=en). Art 267 Treaty on the Functioning of the European Union specifies that the CJEU shall have jurisdiction to give preliminary rulings concerning both the interpretation of the treaties and the validity and interpretation of the institutions, bodies, offices or agencies of the Union. Additional bodies in Ireland that have made references to the CJEU include the Labour Court, the Appeals Commissioners and the Equality Tribunal.

${ }^{139}$ See Cases C-327/18 Minister for Justice and Equality v RO ECLI:EU:C:2018:733; C-325/18 Hampshire County Council v CE and NE ECLI:EU:C:2018:739; C-216/18 LM ECLI:EU:C:2018:586; C-237/15 Minister for Justice and Equality $v$ Francis Lanigan ECLI:EU:C:2015:474; C-376/14 C v M ECLI:EU:C:2014:2268; C-92/12 Health Service Executive $v$ SC and AC ECLI:EU:C:2012:255; C-400/10 J McB $v$ LE ECLI:EU:C:2010:582.

${ }^{140}$ See generally the work of M Broberg and N Fenger Preliminary References to the European Court of Justice (Oxford: Oxford University Press, $2^{\text {nd }}$ edn, 2014); Chalmers et al, above n 127, pp 166-169. See the seminal work of Fahey examining the interaction between the Irish courts and the Court of Justice via the preliminary reference procedure: E Fahey Practice and Procedure in Preliminary References to Europe: 30 Years of Article 234 EC Case law from the Irish Courts (Dublin: First Law, 2006). See also M Broberg and N Fenger 'Variations in Member States' preliminary references to the Court of Justice - are structural factors (part of) the explanation?' (2013) 19(4) European Law Journal 488.

${ }^{141}$ See the European Court annual report with statistics of judicial activity at http://curia.europa.eu/jcms/upload/docs/ application/pdf/2016-08/rapport_annuel_2015_activite_judiciaire_en_web.pdf. On the different practices of national court see generally T Pavone and RD Keleman 'The evolving judicial politics of European integration: the European Court of Justice and national courts revisited' (2019) European Law Journal 1; Broberg and Fenger (2014), above n 140, ch 2,
} 
partly be as a result of reluctance by the courts to make references, ${ }^{142}$ particularly on the basis of the acte clair doctrine ${ }^{143}$ - although this may not be limited to the Scottish courts. ${ }^{144}$ Nonetheless, the infrequent resort to sending preliminary references may simply partially reflect the significantly lower level of EU case law generally in the Scottish courts. ${ }^{145}$ Despite the dearth of preliminary rulings in the Scottish context, the rulings in the two most recent disputes were of considerable significance; the first in Scotch Whisky Association and Others $v$ Lord Advocate, in relation to substantive EU law on free movement of goods and rules designed to enhance public health, and the latter, Wightman \& Others $v$ Secretary of State for Exiting the EU, in the context of a constitutional dispute regarding the Article 50 withdrawal from the EU process.

The number of references from the Irish Supreme Court shows a robust dialogue with the CJEU and the marked openness of the Supreme Court to make references since it first did so in the 1980s. ${ }^{146}$ References from Ireland address a wide range of topics. Some had a significant impact upon the EU itself. In particular Pringle $v$ Government of Ireland provided the mechanism through which one of the most important judgments issued by the CJEU on the EU's Economic and Monetary Union was adopted. ${ }^{147}$ The CJEU's ruling, which was facilitated by the reference from the Irish Supreme Court, affirmed the legality of the European Council's decision to amend the TFEU and permit the creation of the European Stability Mechanism, a central pillar of the EU's response to the fiscal crises. ${ }^{148}$ Schrems $v$ Data Protection Commissioner, which was the result of a preliminary reference from the Irish High Court, had wide reaching ramifications not only for the EU's data protection regimes, but also extra-territorial impacts in how the EU and its Member States share data with third countries, resulting in the EU-US Safe Harbour Agreement being declared invalid by the CJEU. ${ }^{149}$ The CJEU's decision in effect prohibits the generalised access of public authorities to

which notes a wide variation in resort to the procedure across Member States due to the number of cases before the national courts that potentially involve EU law. The population size of each country is also highly relevant. See also B Rodger (ed) Article 234 and Competition Law (Kluwer Law International, 2008); C Harding 'Who goes to court in Europe' (1992) 17 European Law Review 105.

${ }^{142}$ Indeed, in a number of the 534 cases, the issue was raised but the court rejected the possibility of a reference. See R Lane 'Article 234: a few rough edges still' in M Hoskins and W Robinson (eds) A True European: Essays for Judge David Edward (Oxford: Hart Publishing, 2004) p 327.

${ }^{143}$ The acte clair doctrine is an exception to the general requirement under Art 267(3) Treaty on the Functioning of the European Union that national courts or tribunals are obligated to make a reference to the CJEU if there exists no remedy under national law against its decision. The doctrine permits national courts and tribunals to refrain from making a reference where the 'correct application of EU law is so obvious as to leave no scope for any reasonable doubt': see C-283/81 Srl CILFIT and Lanificio di Gavardo SpA v Ministry of Health EU:C:1982:335. See generally A Kornezov 'The new format of the acte clair doctrine and its consequences' (2016) 53 Common Market Law Review 1317.

${ }^{144}$ In the following cases in the period, the Scottish court rejected the possibility of a reference: $O v$ Aberdeen District Council [2017] CSOH 9; Al v Advocate General for Scotland [2015] CSOH 15; Christian Institute v Lord Advocate [2015] $\mathrm{CSOH}$ 7; McGeoch $v$ Lord President of the Council [2013] UKSC 63; Scotch Whisky Association and Others $v$ Lord Advocate [2013] CSOH 70 (note later reference supra on appeal by Inner House); AA (Turkey) v Secretary of State for the Home Department [2013] CSOH 58; Moohan, Petitioner [2013] CSOH 199; Z v Secretary of State for the Home Department [2013] CSIH 16; Morrison-Low v Paterson's Executors [2012] CSIH 10; Angus Growers $v$ Scottish Ministers [2012] CSIH 92 and Russell $v$ Transocean International Resources Ltd [2010] CSIH 82.

${ }^{145}$ See eg Broberg and Fenger (2014), above n 140, p 48. See also Harding, above n 141.

${ }^{146}$ Case 182/83 Robert Fearon and Co Ltd $v$ Irish Land Commission [1984] ECR 3677.

${ }^{147}$ Pringle v Government of Ireland [2012] IESC 47; Case C-370/12 Pringle v Government of Ireland ECLI:EU:C:2012:756;

${ }^{148}$ See European Council Decision 2011/199/EU amending Art 136 of the Treaty on the Functioning of the European Union [2011] OJ L91/1. For a detailed analysis of Pringle see B de Witte and T Beukers 'The Court of Justice approves the creation of the European Stability Mechanism outside the EU legal order: Pringle' (2013) 50(3) Common Market Law Review 805; S Adam and F Meno Parras 'The European Stability Mechanism through the legal meanderings of the Union's constitutionalism: comment on Pringle' (2013) 38(6) European Law Review 848; A Hinarejos 'The Court of Justice of the EU and the legality of the European Stability Mechanism' (2013) 72(2) Cambridge Law Journal 237.

${ }^{149}$ Case C-362/14 Maximillian Schrems v Data Protection Commissioner ECLI:EU:C:2015:650; Schrems v Data Protection Commissioner [2014] IEHC 310. For a detailed analysis see C Kuner 'Reality and illusion in EU data transfer regulation post Schrems' (2017) 18 German Law Journal 881. See also P Roth 'Adequate level of data protection in third countries post-Schrems and under the General Data Protection Regulation’ (2017) 25(1) Journal of Law Information and Science 49. 
electronic communications as 'compromising' individuals' fundamental rights to respect for private life under Article 7 of the Charter. ${ }^{150}$

Both cases suggest that the courts of a small EU Member State may influence the development of EU law in important ways. This runs contrary to the idea that small Member States face challenges inshaping the EU's policies and laws. ${ }^{151}$ Panke attributes these challenges to two factors: first, the comparatively limited bargaining power of smaller states; and secondly, their constrained fiscal resources compared to larger Member States. ${ }^{152}$ These examples demonstrate the impact that small EU Member States, such as Ireland, may have on political and constitutional developments of the EU outside the political sphere through distinctly legal mechanisms. Similarly, the High Court's preliminary reference to the CJEU in the case of Clemer, ${ }^{153}$ concerning deficiencies in the independence of the Polish judiciary, demonstrates that courts from any Member State can act set checks and balances on other Member States' compliance with Union values and legal norms. A similar observation can be made of Minister for Justice and Equality vOG and PI, included in our preliminary reference dataset, where the Supreme Court not only acted as a check on the German Public Prosecutors structural independence, but exercised considerable influence over another Member State's internal arrangements, in relation to the European Arrest Warrant in this instance, leading to a reshuffling of institutional balance within the state via the use of the preliminary reference procedure. ${ }^{154}$

\section{Reflections on the application of EU law in the courts of Scotland and Ireland}

There are four main conclusions that can be drawn from this comparative study. First, EU law matters. The data demonstrates, through a snapshot of a ten-year period, how routinised and embedded the EU's legal order is within the case law and judicial processes of both Scotland and Ireland's legal systems, indicating a substantive internalisation of EU law, principles and norms as a normative part of their domestic legal orders. Furthermore the analysis of the most commonly occurring subject-matter of case law for both jurisdictions points to their dependence on supranational laws and governance structures in the environmental law context, as well as their mutual benefit from cooperative systems such as the Dublin Regulations for dealing with immigration, asylum and refugee matters. This study is important, as it will allow measurement of the shift in reliance on EU law in the Scottish courts before and post-Brexit. ${ }^{155}$ Specifically in the Irish context the question arises as to the impacts the

\footnotetext{
${ }^{150}$ Kuner, above n 149.

${ }^{151} \mathrm{~B}$ Thorhallsson 'The size of states in the European Union: theoretical and conceptual perspectives' (2006) 28(1) European Integration 7; S Bunse et al 'Is the Commission the small member states' best friend?' (2005) (9) Swedish Institute for European Studies, available at http://www.sieps.se/en/publications/2005/is-the-commission-the-small-memberstates-best-friend-20059/Sieps-2005-9.pdf; B Laffan 'Managing Europe from home in Dublin, Athens and Helsinki: a comparative analysis' (2006) 29(4) West European Politics 687.

${ }^{152} \mathrm{D}$ Panke 'Small states in the European Union: structural disadvantages in EU policy-making and counter-strategies' (2010) 17(6) Journal of European Public Policy 799.

${ }^{153}$ Case C-216/18 Minister for Justice v LM ECLI:EU:C:2018:586.

${ }^{154}$ Joint Cases C-508/18 and C-82/19 PPU Minister for Justice and Equality $v$ OG and PI ECLI:EU:C:2019:456. Note that while Case C-508/18 formed part of the dataset of preliminary references from the Irish courts during the period of study, Case C-82/19 PPU did not. However, these cases were heard jointly as they raised similar issues; B de Witte 'The Lisbon Treaty and national constitutions: more or less Europeanisation?' in C Closa (ed) The Lisbon Treaty and National Constitutions: Europeanisation and Democratic Implications, ARENA Report No 3/09, Oslo. See generally I Maher and R Riordan The Supreme Court and EU Law: Reshuffling Institutional Balance (12 December 2019) UCD Working Papers in Law, Criminology \& Socio-Legal Studies Research Paper No 16/2019.

${ }^{155}$ The European Union (Withdrawal Agreement) Act 2020 contains provision in s 26(1)(d) to allow Ministers to issue regulations to any 'relevant court or tribunal' on how to interpret, and even to disapply, EU law retained via the 2018 Act. For a discussion on this specific provision and its potential ramifications see T Konstadinides and R Sallustio 'Clause 26 of the European Union (Withdrawal Agreement) Bill 2019-20: an exercise of constitutional impropriety' UK Constitutional Law Association Blog (January 2020), available at https://ukconstitutionallaw.org/2020/01/14/theodore-konstadinides-and-riccardo-sallustio-clause-26-of-the-european-union-withdrawal-agreement-bill-2019-20-an-exercise-of-constitutional-impropriety/. See the Government response to the consultation on the departure from retained EU case law by UK
} 
UK's departure will have on Irish courts generally, and more fundamentally for the common law within a Union that will be more dominated by civil law countries. ${ }^{156}$ Those ramifications are uncertain but as an English language common law jurisdiction, there may be an increase in transnational commercial disputes before the Irish courts and a greater openness to the civil law.

Secondly, and related to the first point, the Irish courts, despite a slightly smaller population, have far more cases where EU law is raised than the Scottish courts. While the data itself does not reveal why this is the case, it may provide at least a partial explanation for the significantly lower number and proportion of preliminary references to the European Court from the Scottish courts compared with their Irish counterparts. Thirdly, EU matters for private law relations as well as relations between individuals and the state, a trend identified for both jurisdictions. Fourthly, for both jurisdictions in the civil law domain (which these studies are limited to), migration, asylum and refugee law and environment and planning are the two most significant areas where EU law is evident. Both fields are relatively new, and so the law is less settled. Migration necessarily involves people crossing borders and hence the zone of EU influence readily emerges. EU law on the environment has grown with many of the issues pertaining not to cross-border issues but to concerns that are often local and linked to the EU requirement of an environmental impact assessment for development. ${ }^{157}$

The Scottish and Irish courts can be relied on to have regard to and implement EU law in civil law cases, in both judicial review proceedings and in cases concerning private relationships. ${ }^{158}$ National courts are critical to the integration and application of EU law within domestic legal systems, and we can see for both jurisdictions that purely on a quantitative level, there is activity across the higher courts and across legal issues that pertain to EU law. The studies here go much further than preliminary references, as in fact there are very few references (especially in the Scottish courts) compared to the number of times EU law is raised. This arguably serves to underline the extent to which EU law is now routinised and established within these domestic legal systems and provides a benchmark against which to measure the degree of disruption and/or fracture that Brexit may engender in different ways in both jurisdictions.

\section{Conclusions}

This paper has presented and compared data on the consideration and application of EU law by the Irish and Scottish courts between 2009-2018, building on Rodger's study on the first 40 years of EU Law in Scotland, and Fahey's work on preliminary references in Ireland over the same period. Comparison is not straightforward despite the proximity, common language, and shared history.

\footnotetext{
courts and tribunals, CP303, October 2020, https://assets.publishing.service.gov.uk/government/uploads/system/uploads/ attachment_data/file/926811/departure-eu-case-law-uk-courts-tribunals-consultation-response.pdf.

${ }^{156}$ See G Hogan 'Laws in common: what is the future of the common law within the European Union after Brexit?' (2019) 26(1) The Irish Bar Review 25.

${ }^{157}$ See eg North East Pylon Pressure Campaign v An Bord Pleanála (No 2) [2016] IEHC 490. See also Directive 2011/92/EU on the assessment of the effects of certain public and private projects on the environment [2011] OJ L 26/1 and Directive 2001/42/EC on the assessment of the effects of certain plans and programmes on the environment [2001] OJ L 197/30.

${ }^{158}$ For Scottish civil law cases see for example Arriva Scotland West Ltd $v$ Glasgow Airport Ltd [2011] CSOH 69, Scotch Whisky Association v Lord Advocate [2013] CSOH 70, 2013 SLT 776 (and Inner House [2014] CSIH 38, 2014 GWD 17-309 and CJEU [2016] 2 CMLR 27 and Inner House again [2016] CSIH 77, 2016 SLT 1141), Trump International Golf Club Scotland Ltd $v$ Scottish Ministers [2014] CSOH 22, 2014 SLT 406 (and Inner House [2015] CSIH 46, 2015 SC 673 and Supreme Court [2015] UKSC 74, 2016 SC (UKSC) 25), Wightman v Secretary of State for exiting the European Union [2018] CSOH 8 and 61 (and Inner House [2018] CSIH 18 and 62 and Supreme Court [2018] UKSC 35). For Irish civil law cases see for example C-293/12 and C-594/12 Digital Rights Ireland and Seitlinger $v$ Minister for Communications, Marine and Natural Resources ECLI:EU:C:2014:238; Maximillian Schrems $v$ Data Protection Commissioner [2014] IEHC 310 \& Case C-362/14 Maximillian Schrems v Data Protection Commissioner ECLI:EU: C:2015:650. For an Irish judicial review case see Case C-378/17 Minister for Justice and Equality \& Others $v$ Workplace Relations Commission ECLI:EU:C:2018:979. See generally I Maher and R Riordan The Supreme Court and EU Law: Reshuffling Institutional Balance (12 December, 2019) UCD Working Papers in Law, Criminology \& Socio-Legal Studies Research Paper No 16/2019.
} 
Nonetheless, the exercise highlights some similarities and differences and, perhaps most significantly, sets down a marker against which to measure differences between the two jurisdictions at the end of the first decade following Brexit. Substantive analysis of EU law is common in both jurisdictions, but this sort of data analysis is not. The paper shows the value of understanding how often EU law is raised (in both jurisdictions, EU law is raised in a very small number of cases overall) and in what fields, to give a better understanding of those areas of the law that are most likely to arise in a domestic context. This in turn suggests in Scotland those fields - environment and migration - which will be most affected by Brexit. Finally, the German Constitutional Court handed down its controversial judgment in Weiss ${ }^{159}$ recently, which in part is forcing a reappraisal of the way national courts, and especially constitutional courts, perceive of and carry out their role as EU courts. The question of when, how often and in what fields EU law is raised on a day-to-day level in domestic courts remains important and underpins the larger constitutional questions of competence and the collegiality that must now be grappled with anew.

\footnotetext{
${ }^{159}$ BVerfG, Judgment of the Second Senate of 05 May 2020 - 2 BvR 859/15.
}

Cite this article: Rodger B, Maher I, Riordan R (2021). A decade of EU law in the courts of Scotland and Ireland: national legal systems compared. Legal Studies 41, 311-335. https://doi.org/10.1017/lst.2020.46 